zeszyt $149,2017,851-112$

doi: 10.4467/20833113PG.17.011.6927

Instytut Geografii i Gospodarki Przestrzennej UJ

Wydawnictwo Uniwersytetu Jagiellońskiego

\title{
DANE ZASTANE - OCENA UŻYTECZNOŚCI DO BADANIA KONFLIKTÓW SPOŁECZNYCH WOKÓŁ OBSZARÓW CHRONIONYCH W TRZECH SKALACH PRZESTRZENNYCH ${ }^{1}$
}

\author{
Marcin Rechcinski, Jarostaw Balon, Matgorzata Grodzińnka-Jurczak
}

\section{Secondary data: Evaluation of usefulness for studying social conflicts around protected areas in three spatial scales}

\begin{abstract}
Secondary data comprise resources collected in various sectors of social life, independently from the researcher undertaking their analyses. Collecting such data is usually less time consuming and less costly compared to reactive studies, thus, each time when planning a research study, inclusion of secondary data should be considered. This specifically requires: 1) usage of systematic, multi-criteria evaluation methods; 2) separate evaluation of certain categories of secondary data; 3 ) separate reference to each of the research specific aims. The following paper presents an example of such an evaluation that meets all the criteria mentioned above. Using a point grading technique we assessed usefulness of three categories of secondary data (scientific literature, data used in content analysis and content of the public statistics) to meet all three specific aims of an interdisciplinary research project conducted by the same authors. Each of the aims differs in a) spatial scale of analyses (regional, local and topological) and b) dominant form of enquiry (quantitative, qualitative and qualitative accompanied with the use of GIS techniques). The results suggest usefulness of the technique in the context of multifaceted research projects: final evaluation scores for particular secondary data categories differed substantially depending on the specific aim. However,
\end{abstract}

\footnotetext{
${ }^{1}$ Wyniki opublikowane w niniejszej publikacji stanowią element badań finansowanych ze środków Narodowego Centrum Nauki w ramach projektu nr 2015/19/N/HS4/00359.
} 
we suggest all the analysts to perform a deep insight into the evaluation process itself before deciding to replace reactive research with secondary data analyses. Among others, this is because weights assigned to certain criteria of the evaluation process are often dependent on organisational capacity of a particular research project. At the same time, exemption of the proposed stage of research planning may result in various negative consequences, e.g. 1) reduction in funding perspectives due to weak justification of the planned costs, or 2) lowering research scientific value of the study due to a lack of critical insight into the data, which are out of actual analyses.

Keywords: secondary data, usefulness assessment, social conflicts, protected areas, point grading technique

Zarys treści: Dane zastane to źródła będące efektem dokumentowania różnych dziedzin życia społecznego, niezależne od naukowca podejmującego się ich wtórnej analizy. Ponieważ pozyskanie tych źródeł zazwyczaj jest mniej czaso- i kosztochłonne od badań reaktywnych, ich włączenie do procedury badawczej powinno być rozważane każdorazowo na etapie planowania prac. Wymaga ono jednak: (1) stosowania systematycznych, wielokryterialnych metod oceny; (2) osobnego rozpatrywania poszczególnych kategorii danych zastanych; (3) odrębnego odnoszenia się do każdego celu szczegółowego badań. Artykuł prezentuje przykład ewaluacji spełniającej powyższe warunki. Wykorzystując technikę bonitacji punktowej, oceniono użyteczność trzech kategorii danych zastanych (opublikowane opracowania naukowe, materiały wykorzystywane w analizie treści oraz zawartość statystyk publicznych) do realizacji trzech celów szczegółowych interdyscyplinarnego projektu naukowego, różniących się (a) skalą przestrzenną analiz (regionalna, lokalna i miejscowa); oraz (b) przyjmowanym podejściem metodycznym (badania ilościowe, jakościowe oraz jakościowe z wykorzystaniem technik GIS). Wyniki sugerują skuteczność przyjętej techniki w kontekście projektów wieloaspektowych końcowe oceny użyteczności poszczególnych kategorii danych różnią się w zależności od celu szczegółowego. Postulowany jest jednak silny wgląd w sam proces oceny przed podjęciem ostatecznej decyzji o zastąpieniu badań reaktywnych analizą danych zastanych. Często decydujące znaczenie mają bowiem możliwości organizacyjne projektu, które istotnie wpływają na wagę poszczególnych kryteriów oceny. Pominięcie proponowanego etapu planowania badań może jednak skutkować szeregiem negatywnych konsekwencji, np. obniżeniem perspektywy finansowania badań z uwagi na zbyt słabe uzasadnienie zaplanowanych kosztów lub ograniczeniem wartości naukowej pracy ze względu na krytyczną ocenę jedynie tych danych, które zostały włączone do bezpośrednich analiz.

Stowa kluczowe: dane zastane, ocena użyteczności, konflikty społeczne, obszary chronione, bonitacja

\section{Wstęp}

Pojęcie danych zastanych odnosi się do szerokiego zakresu źródeł powstających wskutek procesów dokumentowania wielu dziedzin życia publicznego (Sułek 2002; Makowska, Boguszewski 2013). Procesy te realizowane są w różnych celach, zarówno prywatnych, jak i służbowych, niemniej zazwyczaj niezależnych od celu 
naukowego przyjętego przez badacza analizującego te źródła (Frankfort-Nachimas, Nachimas 2001). Z tego powodu część metodologów nauk społecznych (np. Babbie 2013) zalicza badania wykorzystujące dane zastane do badań niereaktywnych, czyli takich, w których badacz nie ingeruje w rzeczywisty obiekt analizy bądź charakter analizowanego zjawiska.

Dane zastane klasyfikowane są ze względu na różne kryteria (m.in. Makowska, Boguszewski 2013), m.in.:

- sposób kodowania informacji (np. materiały tekstowe, utwory plastyczne, muzyczne, filmowe czy dane liczbowe $)^{2}$;

- formę i sposób powstania (pierwotne - w postaci surowej, i wtórne - przetworzone np. do postaci raportów z analizy danych pierwotnych);

- rozdzielność czasową (rejestrowane: jednorazowo, w sposób cykliczny bądź ciągły); - źródło pochodzenia (prywatne lub publiczne);

- poziom obiektywizmu (np. uzyskane w drodze pomiarów cech fizycznogeograficznych bądź badań postaw lub opinii).

Wewnętrzne zróżnicowanie źródeł wtórnych, jak i zarysowana wyżej istota tych danych sprawiają, że decyzje o ich wykorzystaniu na poszczególnych etapach procesu badawczego zawsze powinny być poprzedzone niezależnymi analizami ich użyteczności ze względu na przyjęte cele badawcze. W większości sytuacji najlepszym założeniem jest podejmowanie badań empirycznych dopiero w przypadku stwierdzenia negatywnego wyniku wspomnianej oceny. Postulowanie tego podejścia wynika z większej czasochłonności i kosztochłonności przeważającej grupy badań reaktywnych (Makowska, Boguszewski 2013). W pracy współczesnego naukowca kwestie te nabierają szczególnego znaczenia, gdyż uwzględnienie podstawowych zasad odnoszących się do zarządzania projektami jest coraz częściej wymogiem skutecznej realizacji zamierzeń badawczych (vom Brocke, Lippe 2010).

Niestety systematyczna ocena alternatyw metodycznych na etapie planowania badań wciąż podejmowana jest rzadko. Przyjęcie określonej metodyki prac w projekcie naukowym zazwyczaj uzasadniane doświadczeniem i wiedzą badacza odnośnie do skuteczności poszczególnych metod. Nierzadko decyzje te poparte są również bogatą literaturą, co dodatkowo wzmacnia wrażenie racjonalności dokonywanych wyborów. Jednocześnie jednak utrudnione jest wówczas szersze spojrzenie na dostępne możliwości badawcze, szczególnie zaś na potencjał tych metod, które nie wymagają zaangażowania naukowca w proces zbierania danych pierwotnych. Zdaniem autorów niniejszego opracowania konieczne jest położenie nacisku na relatywną ewaluację użyteczności stosowanych metod, mając na uwadze fakt,

\footnotetext{
${ }^{2}$ Kryterium sposobu kodowania informacji nie determinuje jeszcze grupy metod, w ramach której analizowane są dane materiały - np. materiały tekstowe czy filmowe mogą z powodzeniem podlegać zarówno studiom ilościowym, jak i jakościowym (por. Babbie 2013).
} 
że perspektywa uzyskania finansowania badań w dużej mierze zależy od pozytywnej oceny wykonalności projektu badawczego oraz racjonalności planowanych kosztów (www.ncn.gov.pl, dostęp: 28.11.2016).

Niniejszy artykuł stanowi propozycję usystematyzowania procesu oceny możliwości wykorzystania danych zastanych w toku realizacji konkretnego projektu naukowego podejmującego problematykę konfliktów społecznych w kontekście przestrzennym obszarów chronionych. Schemat założonego w projekcie postępowania badawczego ma trójdzielny charakter, przy czym każdy z trzech etapów: (1) odpowiada na inny cel szczegółowy badań; (2) jest realizowany w innej skali przestrzennej; (3) wykorzystuje inną grupę metod badawczych. Tak zarysowana struktura projektu ułatwia usystematyzowanie procesu oceny użyteczności danych zastanych na każdym etapie prac, jednocześnie wymusza wieloaspektowość tej procedury. Czyni to omawiane studium przypadku odpowiednim do celów niniejszej prezentacji metodycznej.

\section{Metody}

Aby proces ewaluacji spełniał podstawowe kryteria procesu naukowego, zdecydowano się odnieść go do teorii ocen. Kostrowicki (1992) zaznacza, że każdy proces wartościowania ma charakter subiektywny, gdyż jest on nierozerwalnie uzależniony od poglądów czy wiedzy osoby oceniającej. Możliwe jest jednak wyraźne odróżnienie sądów emocjonalnych (Sołowiej 1987) lub autotelicznych od instrumentalnych, czyli odnoszących się do konkretnych celów ewaluacji. Naukową użyteczność ocen zwiększa także (a) wyraźne określenie kryteriów oceny; oraz (b) konsekwentne stosowanie przyjętych technik ewaluacji (Kostrowicki 1992). Wreszcie, proces ten powinien przebiegać w określonej sekwencji, odzwierciedlającej podkreślaną przez autorów etapowość oceniania (Bródka 2010). Wymogi te można wyrazić w postaci funkcji (por. Wawrzyńczak 1981), której składowe zostały szczegółowo scharakteryzowane w odniesieniu do procesu ewaluacji omawianego w niniejszym artykule: Wo (c): $O b \times(K r, O s)$----- Oc, gdzie

Wo (c) to proces oceniania ze względu na przyjęty cel;

$\mathrm{Ob}$ - zbiór ocenianych obiektów;

$K r$ - przyjęte kryteria i techniki ewaluacji;

Os-osoba dokonująca oceny, jej doświadczenie i wiedza rozumiane jako specyficzne kryterium dodatkowe;

Oc-ostateczna ocena. 


\section{Cel oceny}

W niniejszym przypadku cel oceny dotyczy możliwości wykorzystania danych zastanych w toku realizacji analizowanego projektu naukowego. Zakłada on zidentyfikowanie zależności pomiędzy obszarową formą ochrony przyrody a strukturalnymi i przestrzennymi cechami konfliktów w obrębie systemów społeczno-ekologicznych obszarów chronionych województwa małopolskiego. Strukturalne cechy konfliktów, jako wyraźnie wyodrębnione od charakterystyk emocjonalnych i behawioralnych, obejmują przede wszystkim uwarunkowania konfliktotwórcze oraz takie wymiary konfliktów, jak przedmiot sporu, proces jego rozwoju czy relacje pomiędzy poszczególnymi grupami interesów (tzw. interesariuszami) (Hellström 2001; White i in. 2009). Z kolei przestrzenne cechy konfliktów odnoszą się do tych wartości/przedmiotów zainteresowania poszczególnych grup interesariuszy, które są możliwe do zlokalizowania na mapie w skali miejscowej (np. Brown, Raymond 2014). W projekcie wykorzystywana jest koncepcja systemów społeczno-ekologicznych (ang. socio-ecological systems, SES), która zakłada odejście od badania obszarów chronionych wyłącznie w obrębie ich granic administracyjnych, na które to terytoria człowiek jedynie oddziałuje bądź pozyskuje określone korzyści w wyniku ich użytkowania. Współczesny paradygmat SES zakłada traktowanie obszaru chronionego wraz z jego otoczeniem społecznym jako ściśle współzależnego systemu (Mace 2014; Palomo i in. 2014), kształtowanego zarówno wskutek realizowania przyjętej polityki ochrony przyrody, jak i w wyniku możliwości adaptacyjnych chronionego środowiska wobec generowanych/redukowanych presji bezpośrednich i pośrednich.

Ze względu na zasygnalizowaną trójetapowość projektu proces oceny odnosić się będzie do jego celów szczegółowych, z którymi silnie powiązana jest skala przestrzenna analizy oraz dobór metod badawczych. Założono:

1) określenie ogólnych powiązań pomiędzy formą ochrony przyrody a strukturalnymi cechami konfliktów (skala regionalna, badania ilościowe);

2) poznanie wpływu formy ochrony przyrody na strukturalne cechy konfliktów w skali lokalnej (badania jakościowe);

3) określenie charakterystyki przestrzennej konfliktów w skali miejscowej, z uwzględnieniem formy ochrony przyrody jako czynnika różnicującego (skala miejscowa, badania jakościowe z wykorzystaniem technik GIS).

\section{Zbiór ocenianych obiektów}

Na potrzeby niniejszego procesu ewaluacji oceniane obiekty (dane zastane) zostały podzielone na trzy grupy. Za kryterium podziału przyjęto powszechność wykorzystania danej kategorii źródeł wtórnych w ramach trzech podstawowych metod analizy 
danych zastanych (Makowska, Boguszewski 2013): (1) desk research³; (2) analizy treści (ang. content analysis); oraz (3) wtórnej analizy statystycznej. Zastosowanie tego klucza było konieczne ze względu szeroką i zróżnicowaną gamę przykładów źródeł wtórnych, która uniemożliwiłaby ich niezależną ocenę w przyjętych ramach artykułu, a ich zbiorczą ewaluację uczyniłaby zbyt dalece upraszczającą badaną problematykę. Każda z wymienionych metod analizy skłania ku wykorzystaniu konkretnych kategorii źródeł wtórnych, niemniej naukowiec prowadzący badania niereaktywne ma dużą swobodę w doborze materiału do poszczególnych analiz. W ramach niniejszej pracy zdecydowano się zatem na precyzyjne określenie poszczególnych zbiorów ocenianych obiektów dla zapewnienia ich rozłącznego charakteru.

Do grupy nr 1 włączono jedynie opublikowane opracowania naukowe podejmujące problematykę zbieżną z celami szczegółowymi projektu (bez względu na formę ich udostępnienia - tradycyjną, kartograficzną, cyfrową itp.). Zawężono tym samym metodę desk research do studiów literaturowych o charakterze eksploracyjnym, zmierzających do oceny aktualnego stanu wiedzy w danej dziedzinie oraz identyfikacji ewentualnych luk badawczych (Makowska 2013; Świderek 2013). Warto zauważyć, że przy tak określonym zbiorze obiektów jedynie negatywna ocena ich użyteczności warunkowałaby zasadność podjęcia jakichkolwiek własnych zamierzeń badawczych, gdyż tylko wówczas zamierzenia te mogłyby spełniać podstawowe kryterium rozwoju naukowego, jakim jest oryginalność tworzonych prac (Pieter 1967). Do zbioru źródeł wtórnych ocenianych w tej grupie nie włączono danych wykorzystywanych w szerzej ujmowanym desk research, którego wynikiem są kompletne raporty tematyczne z kwerendy obejmującej bardzo różnorodne kategorie źródeł wtórnych (Makowska 2013). Większość z nich może podlegać bardziej systematycznej analizie w ramach pozostałych dwóch wymienionych metod, zatem na potrzeby niniejszego artykułu oceniano je wyłącznie jako elementy drugiego i trzeciego zbioru obiektów.

Grupa nr 2 stanowi zbiór zdecydowanie najbardziej liczny; znajdują się w nim wszystkie kategorie materiałów, które mogą być wykorzystywane w ramach analizy treści (zarówno ilościowej, jak i jakościowej) poszerzonej o elementy analizy dyskursu i zawartości, wyróżnianych przez Makowską i Boguszewskiego (2013) oraz Maj (2013) jako odrębne metody badawcze ${ }^{4}$. Na listę przykładów źródeł ocenianych w ramach tej kategorii składają się:

\footnotetext{
${ }^{3}$ W polskojęzycznych pracach metodycznych (np. Makowska 2013; Bednarowska 2015) termin desk research używany jest w brzmieniu oryginalnym. Jest pojęciem węższym niż ,analiza danych zastanych” (do której zalicza się również m.in. analiza treści i wtórna analiza statystyczna), ale szerszym niż „przegląd literatury" (który obejmuje także krytyczne wykorzystanie informacji pozyskanych z różnych źródeł w ramach realizacji odrębnego celu badawczego).

${ }^{4}$ Analiza treści definiowana jest najogólniej jako technika systematycznego badania treści przekazów w poszukiwaniu określonych prawidłowości. Analiza zawartości jest pojęciem szerszym, obejmującym również badanie formy przekazu czy sposobu przedstawienia danej informacji (Maj 2013). Studia o równie szerokim zakresie prac, ale skoncentrowane na przekazach werbalnych oraz charakteryzujące się większą otwartością procesu kategoryzacji określa się mianem analizy dyskursu (np. Makowska, Boguszewski 2013).
} 
- akty prawne, zarządzenia, polityki itp. (pod kątem analizy kontekstu politycznoprawnego konfliktów społecznych wokół obszarów chronionych);

- dokumenty wewnętrzne jednostek samorządu terytorialnego, organizacji pozarządowych czy instytucji ochrony przyrody (pod kątem analizy polityki wewnętrznej poszczególnych instytucji odnośnie do badanych konfliktów);

- materiały kartograficzne (głównie mapy tematyczne przygotowywane i pozostające w dyspozycji zidentyfikowanych interesariuszy instytucjonalnych);

- sprawozdania ze spotkań publicznych, konsultacji społecznych itp. (pod kątem obiektywnej identyfikacji strukturalnych cech konfliktów na podstawie oficjalnych dokumentów);

- artykuły prasowe;

- strony www, fora internetowe;

- materiały telewizyjne, radiowe, także materiały filmowe i dźwiękowe umieszczone w internecie (pod kątem analizy zróżnicowanych przekazów dotyczących badanej problematyki);

- ulotki, afisze (w szerszym zakresie analizy ich zawartości);

- rejestry policyjne, samorządowe czy rządowe dotyczące konkretnych aktów zachowań konfliktowych (jedynie w charakterze danych wspomagających identyfikację strukturalnych cech konfliktów przez pryzmat ich przejawów behawioralnych).

Z szerokiej listy kategorii źródeł stanowiących częsty przedmiot analizy treści ze względu na przyjęte założenia dotyczące etyki badań wykluczono dokumenty osobiste interesariuszy innych niż instytucjonalni, które nie podlegały wcześniej żadnym formom upublicznienia (np. wskutek umieszczenia ich w internecie).

Grupę nr 3 stanowią dane liczbowe zbierane zgodnie z programem badań statystyki publicznej (Rozporządzenie... 2014), bez rozróżnienia na instytucję publikującą. Nie uwzględniono natomiast zasobów archiwizujących materiał roboczy powszechnych badań sondażowych (np. Polskiego Generalnego Sondażu Społecznego), głównie ze względu na zbyt ogólną skalę przestrzenną agregowanych tam danych.

\section{Kryteria oceny}

Przyjęte kryteria stanowią efekt operacjonalizacji wymiarów jakości danych wyszczególnionych w literaturze przedmiotu (m.in. Frankfort-Nachimas, Nachimas 2001; Sztumski 2010; Kompendium wiedzy... 2012; Babbie 2013; Makowska 2013). Uwzględniono:

1) dokładność (w tym liczbę błędów, niekompletność);

2) aktualność;

3) dostępność (w tym koszt i czas pozyskania, przejrzystość);

4) porównywalność przestrzenną;

5) porównywalność czasową (w tym możliwość powtarzania procesu celem zwiększenia rzetelności prac); 
6) spójność (możliwość swobodnego agregowania);

7) wiarygodność (ocenianą m.in. przez pryzmat prestiżu instytucji publikującej);

8) ilość (w wymiarze konieczności selekcjonowania danych, ale i zapewnienia reprezentatywności próby);

9) obiektywność danych (w tym- ewentualne ryzyko ich nadinterpretacji, obniżającej trafność procesu).

\section{Technika oceny}

W procesie oceny zdecydowano się na zastosowanie techniki bonitacji punktowej (Kostrowicki 1992). Odwołano się do poglądu Wojciechowskiego (1986), zdaniem którego istotą oceny jest konfrontowanie danej rzeczy czy zjawiska z pewnym wzorcem. W wypadku niniejszej ewaluacji nie przyjęto żadnego wzorca idealnego, niemniej ustalono punkt odniesienia, wobec którego przypisywano znak wartości oceny (dodatni bądź ujemny). Wspomnianą kategorią niezależną były dane wywołane, które pozyskano by przez badacza bezpośrednio w toku studiów empirycznych i które odpowiadałyby na identycznie postawione cele szczegółowe projektu. Ze względu na charakter przedmiotu badań oraz określoną koncepcję metodyki stosowanej na poszczególnych etapach prac, w praktyce użyteczność źródeł wtórnych odnoszono do danych uzyskanych w drodze przeprowadzenia wywiadu kwestionariuszowego/ ankiety zdalnej na reprezentatywnej próbie badanych (cel 1), wywiadów pogłębionych ze zidentyfikowanymi przedstawicielami poszczególnych grup interesu (cel 2) oraz tzw. wywiadów PPGIS (ang. Public Participatory Geographic Information Systems), umożliwiających zbieranie dowolnej subiektywnie postrzeganej informacji przestrzennej, umieszczanej przez respondenta na dostarczonym podkładzie mapy (cel 3) (np. Pietrzyk-Kaszyńska i in. 2016).

Zgodnie z wyjściowym założeniem każda grupa obiektów zależnych (kategorii danych zastanych) miała podlegać trzykrotnej ocenie (pod kątem realizacji każdego z trzech celów szczegółowych) według wszystkich wymienionych kryteriów. Zastosowano skalę od -2 (dużo niższa, względem danych wywołanych, użyteczność w kontekście realizacji określonego celu szczegółowego) do +2 (dużo wyższa użyteczność). W niektórych przypadkach stosowano tzw. wartości „zerujące”, które należy interpretować jako dyskwalifikujące wykorzystanie danej kategorii danych do realizacji przyjętego celu szczegółowego. Rezultatem procedury bonitacyjnej było uzyskanie sum ocen cząstkowych dla każdej kategorii danych - w przypadku gdy uzyskiwano wartość dodatnią, konkretną kategorię danych zastanych interpretowano jako bardziej użyteczną od danych wywołanych do realizacji konkretnego celu szczegółowego. Jednoczesne wykorzystanie techniki sumowania ocen cząstkowych oraz wartości ,zerujących” można uznać za przykład integracji metod scalania (Bartkowski 1986) oraz eliminacji (Balon, Maciejowski 2012) cech podlegających ocenie. 


\section{Wyniki}

Pełen proces bonitacji punktowej przeprowadzono łącznie dla sześciu zależności: „kategoria danych zastanych x cel szczegółowy projektu” (tab. 1). Wartości „zerujące” przypisano trzykrotnie: literaturze naukowej (kat. 1) przy ocenie jej użyteczności do realizacji celów szczegółowych nr 1 i nr 3, a także danym stanowiącym zawartość statystyk publicznych (kat. 3) w kontekście ich wykorzystania w ramach celu nr 3 . Pierwsza z decyzji podyktowana została faktem, że nie podjęto dotychczas próby określenia ogólnych powiązań pomiędzy formą ochrony przyrody a strukturalnymi cechami konfliktów na terenie Polski ani dokonania charakterystyki przestrzennej konfliktów w skali miejscowej. Jedyne prace przekrojowe, w których wykorzystywano ilościowy aparat metodyczny (Królikowska 2007; Hibszer 2013) koncentrowały się na określeniu wybranych właściwości systemu społecznego samych parków narodowych, zatem trudno na ich podstawie orzekać o roli innych form ochrony przyrody w kształtowaniu się struktury konfliktów społecznych. Z kolei dostępne dane statystyczne, choć bardzo użyteczne na wyższych poziomach analizy, nie mogą służyć do analiz w skali miejscowej - stanowią one obraz pewnej agregacji przestrzennej, przez co próba ich interpretowania w większych skalach obarczona jest tzw. błędem ekologicznym (Babbie 2013), dyskwalifikującym ich użyteczność. Możliwość wykorzystania w badaniach danych odnoszących się do gospodarstw domowych jest wykluczona ze względu na uregulowania prawne z zakresu tajemnicy statystycznej (Ustawa... 1995). Ponadto sam dobór zmiennych gromadzonych w ramach statystyk publicznych na tym poziomie agregacji nie jest na tyle kompletny, by umożliwił dokonanie na ich podstawie charakterystyki przestrzennej konfliktów w skali miejscowej.

Ocenie poddano możliwość wykorzystania literatury naukowej (kat. 1) do realizacji celu szczegółowego nr 2. W polskim dorobku badawczym znajduje się wiele prac o charakterze jakościowym opisujących sytuacje konfliktowe dla studiów przypadku konkretnych obszarów chronionych województwa małopolskiego (np. Balon 2002; Hibszer 2004; Hibszer, Partyka red. 2005; Kucina 2007; Grodzińska-Jurczak, Cent 2011; Rechciński 2012). Cechami większości tych opracowań są jednak: koncentracja na prezentacji konfliktów w obrębie jedynie wybranych obszarów województwa/ formy ochrony przyrody (z wyraźnym naciskiem na parki narodowe i obszary Natura 2000 - kryterium porównywalności przestrzennej, dokładności i obiektywności), zróżnicowany stopień aktualności prac oraz brak wzajemnie ujednoliconej metodyki badań (w przypadku pojedynczych opracowań metoda analizy nie została nawet precyzyjnie określona - kryterium spójności). Wpływa to na sumaryczną negatywną ocenę użyteczności tych źródeł do realizacji celu szczegółowego nr 2. Jednocześnie jednak ocena tych prac względem kryteriów dostępności, ilości danych oraz ich porównywalności czasowej przyjęła wartości dodatnie. Zadecydowały o nich możliwości organizacyjne wykonawców projektu - samodzielne wykonanie 
Tab. 1. Zastosowanie techniki bonitacji punktowej przy ocenie użyteczności wybranych kategorii danych zastanych do realizacji celów szczegółowych projektu naukowego podejmującego problematykę konfliktów społecznych na obszarach chronionych

Table 1. Usage of point grading technique to evaluate selected categories of secondary data to complete specific aims of a research project on social conflict around protected areas

\begin{tabular}{|c|c|c|c|c|c|c|c|c|c|}
\hline & & & $\begin{array}{l}\text { Kategorie oc } \\
\text { Categories }\end{array}$ & $\begin{array}{l}\text { enianych } \\
f \text { evaluat }\end{array}$ & $\begin{array}{l}\text { I danych } \\
\text { ted secol }\end{array}$ & $\begin{array}{l}\text { zastanyc } \\
\text { idary dat }\end{array}$ & & & \\
\hline & $\begin{array}{l}\text { Literatu } \\
\text { Scientif }\end{array}$ & $\begin{array}{l}\text { a nauko } \\
\text { c literatı }\end{array}$ & & $\begin{array}{r}\text { Dane } \\
\text { w a } \\
\text { Data } \\
\end{array}$ & $\begin{array}{l}\text { wykorzy } \\
\text { analizie t } \\
\text { used in } \\
\text { analysi }\end{array}$ & $\begin{array}{l}\text { tywane } \\
\text { eści } \\
\text { ontent }\end{array}$ & $\begin{array}{l}\text { Zav } \\
\text { Con }\end{array}$ & $\begin{array}{r}\text { vartość } \\
\text { publiczl } \\
\text { tent of } \mathrm{t} \\
\text { statist }\end{array}$ & $\begin{array}{l}\text { tatystyk } \\
\text { nych } \\
\text { he public } \\
\text { ics }\end{array}$ \\
\hline $\begin{array}{l}\text { Kryteria oceny } \\
\text { Criteria of } \\
\text { evaluation }\end{array}$ & 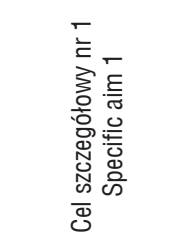 & 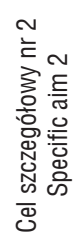 & 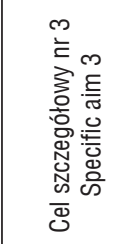 & 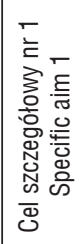 & 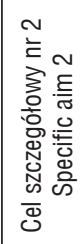 & 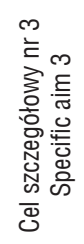 & 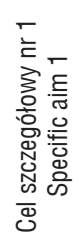 & 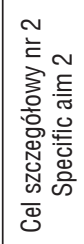 & 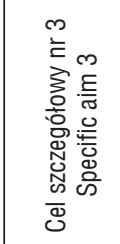 \\
\hline $\begin{array}{l}\text { Dokładność } \\
\text { Accuracy }\end{array}$ & $\begin{array}{c}\text { wartość } \\
\text { „zerująca” } \\
\text { 'resetting' value }\end{array}$ & -1 & $\begin{array}{c}\text { „zerująca" } \\
\text { "resetting' } \\
\text { value }\end{array}$ & -1 & 0 & -1 & -1 & -2 & $\begin{array}{c}\text { wartość } \\
\text { "zerująca" } \\
\text { 'resetting' } \\
\text { value }\end{array}$ \\
\hline $\begin{array}{l}\text { Aktualność } \\
\text { Timeliness }\end{array}$ & $\begin{array}{c}\text { wartość } \\
\text { „zerująca” } \\
\text { ‘resetting' value }\end{array}$ & -1 & $\begin{array}{c}\text { wartość } \\
\text { „zerująca" } \\
\text { 'resetting' } \\
\text { value }\end{array}$ & -1 & 0 & -1 & -1 & -1 & -2 \\
\hline $\begin{array}{l}\text { Dostępność } \\
\text { Accessibility }\end{array}$ & $\begin{array}{c}\text { wartość } \\
\text { „zerująca” } \\
\text { 'resetting' value }\end{array}$ & 1 & $\begin{array}{c}\text { wartość } \\
\text { „Zerująca" } \\
\text { 'resetting' } \\
\text { value }\end{array}$ & 0 & 0 & -1 & 2 & -1 & $\begin{array}{c}\text { wartość } \\
\text { "zerująca" } \\
\text { 'resetting' } \\
\text { value }\end{array}$ \\
\hline $\begin{array}{l}\text { Porównywalność } \\
\text { przestrzenna } \\
\text { Spatial } \\
\text { comparability }\end{array}$ & 1 & -1 & $\begin{array}{c}\text { wartość } \\
\text { „zerująca" } \\
\text { 'resetting' } \\
\text { value }\end{array}$ & -2 & -1 & -2 & 1 & 1 & 0 \\
\hline $\begin{array}{l}\text { Porównywalność } \\
\text { czasowa } \\
\text { Temporal } \\
\text { comparability }\end{array}$ & 0 & 1 & \begin{tabular}{|c|} 
wartość \\
„zerująca" \\
'resetting' \\
value
\end{tabular} & 1 & 2 & 0 & 2 & 2 & 0 \\
\hline $\begin{array}{l}\text { Spójność } \\
\text { Coherence }\end{array}$ & $\begin{array}{c}\text { wartość } \\
\text { „zerująca” } \\
\text { 'resetting' value }\end{array}$ & -2 & \begin{tabular}{|c|} 
wartość \\
„zerująca" \\
'resetting' \\
value
\end{tabular} & -2 & -1 & -2 & 2 & 2 & 2 \\
\hline $\begin{array}{l}\text { Wiarygodność } \\
\text { Credibility }\end{array}$ & 0 & -1 & \begin{tabular}{|c|} 
wartość \\
„zerująca”
\end{tabular} & -1 & -1 & -1 & 0 & 0 & -1 \\
\hline $\begin{array}{l}\text { Ilość } \\
\text { Amount }\end{array}$ & $\begin{array}{c}\text { wartość } \\
\text { „zerująca” } \\
\text { 'resetting' value }\end{array}$ & 2 & $\begin{array}{c}\text { wartość } \\
\text { „zerująca" } \\
\text { 'resetting' } \\
\text { value }\end{array}$ & -1 & 2 & 1 & 2 & 2 & 1 \\
\hline
\end{tabular}




\begin{tabular}{|c|c|c|c|c|c|c|c|c|c|}
\hline \multirow{3}{*}{$\begin{array}{l}\text { Kryteria oceny } \\
\text { Criteria of } \\
\text { evaluation }\end{array}$} & \multicolumn{9}{|c|}{$\begin{array}{l}\text { Kategorie ocenianych danych zastanych } \\
\text { Categories of evaluated secondary data }\end{array}$} \\
\hline & \multicolumn{3}{|c|}{$\begin{array}{l}\text { Literatura naukowa } \\
\text { Scientific literature }\end{array}$} & \multicolumn{3}{|c|}{$\begin{array}{c}\text { Dane wykorzystywane } \\
\text { w analizie treści } \\
\text { Data used in content } \\
\text { analysis }\end{array}$} & \multicolumn{3}{|c|}{$\begin{array}{l}\text { Zawartośś statystyk } \\
\text { publicznych } \\
\text { Content of the public } \\
\text { statistics }\end{array}$} \\
\hline & 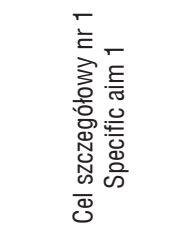 & 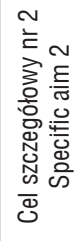 & 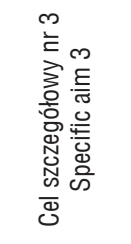 & 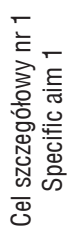 & 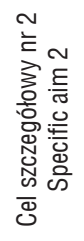 & 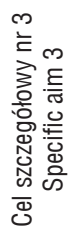 & 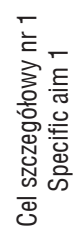 & 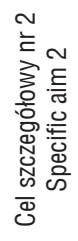 & 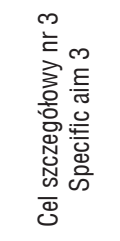 \\
\hline $\begin{array}{l}\text { Obiektywność } \\
\text { Objectivity }\end{array}$ & $\begin{array}{c}\text { wartość } \\
\text { „Zerująca” } \\
\text { 'resetting' value }\end{array}$ & -2 & $\begin{array}{l}\text { wartość } \\
\text { „zerująca” } \\
\text { 'resetting' } \\
\text { value }\end{array}$ & -2 & -2 & -1 & -1 & 0 & $\begin{array}{c}\text { wartość } \\
\text { „zerująca" } \\
\text { 'resetting' } \\
\text { value }\end{array}$ \\
\hline $\begin{array}{l}\text { SUMA } \\
\text { TOTAL }\end{array}$ & $\begin{array}{c}\text { wartości } \\
\text { „zerujące” } \\
\text { 'resetting' values }\end{array}$ & -4 & $\begin{array}{l}\text { wartości } \\
\text { „zerujące" } \\
\text { 'resetting' } \\
\text { values }\end{array}$ & -9 & -1 & -8 & 6 & 3 & $\begin{array}{c}\text { wartości } \\
\text { „Zerujące" } \\
\text { 'resetting' } \\
\text { values }\end{array}$ \\
\hline
\end{tabular}

Dokładna charakterystyka kategorii ocenianych danych zastanych, kryteriów oceny oraz celów szczegółowych projektu została zawarta w tekście artykułu. Uzasadniono też w nim większość przydzielonych ocen bonitacyjnych. Pełne uzasadnienie wszystkich przypisanych ocen zawarto w materiałach dodatkowych dołączonych do opracowania.

A detailed characterization of assessed secondary data categories, criteria of evaluation and specific aims of the projects is included in the main text of the article. Most of the assessment grades are also justified there. A full justification of all the grades can be found in supplementary materials attached to the paper.

badań jakościowych odnoszących się do tak dużej liczby studiów przypadku nie jest wykonalne $\mathrm{w}$ ramach pojedynczego zamierzenia badawczego. Prawie niemożliwe do osiągnięcia jest też powtórzenie uzyskanych w ten sposób wyników empirycznych w wypadku ponowienia badań reaktywnych, co w tym zakresie daje przewagę metodom desk research.

Najszerszą perspektywę wykorzystania danych zastanych w ramach omawianego projektu rozważano w odniesieniu do kategorii nr 2 - źródeł wykorzystywanych w toku analizy treści. Użyteczność tych danych oceniono względem perspektywy realizacji wszystkich trzech celów szczegółowych projektu, niemniej w każdym z tych przypadków sumaryczna ocena przyjmowała wartość ujemną. Na ten wynik najsilniej wpłynęły kryteria: obiektywności, spójności, porównywalności 
przestrzennej oraz wiarygodności danych, jednak ich wpływ na końcowy rezultat był różny w zależności od metod analizy stanowiących punkt odniesienia. Bonitacja wykazała, że źródła ujęte w kategorii nr 2 w najsłabszym stopniu spełniają wymogi badań ilościowych (cel szczegółowy nr 1), głównie ze względu na niesystematyczny charakter, bardzo silne zróżnicowanie wewnętrzne, a także nierównomierne pokrycie przestrzeni województwa małopolskiego przekazami dotyczącymi badanej tematyki. W przypadku badań jakościowych, których istotą jest celowy dobór materiałów do analiz, cechy te stanowiły nieco mniejszy mankament, niemniej wciąż relatywnie tanie i prowadzone według ustalonego scenariusza wywiady pogłębione oceniono jako dostarczające bardziej użytecznych danych do realizacji celu szczegółowego nr 2. Decydująca okazała się niska obiektywność materiałów z kategorii nr 2, stanowiących zbiór przekazów o bardzo zróżnicowanym charakterze i genezie.

Dużym wyzwaniem badawczym byłoby też zrealizowanie celu szczegółowego nr 3 omawianego projektu jedynie na podstawie analizy danych zastanych wyszczególnionych w kategorii nr 2. Wymagałoby to odnajdywania w treści zróżnicowanych przekazów określeń o charakterze werbalnym dotyczących lokalizacji określonych zjawisk społecznych związanych z konfliktami. Te rozproszone i wysoce niekompletne informacje mogłyby być uzupełniane treścią map tematycznych zazwyczaj pozostających w dyspozycji organów publicznych (np. władz samorządowych lub organów zarządzających danymi obszarami chronionymi). Integrowanie tak rozbieżnych w swym charakterze danych (kryterium spójności), w dodatku zazwyczaj nieodnoszących się wprost do analizowanego zagadnienia, oraz próba ich interpretowania pod kątem realizacji przywoływanego celu szczegółowego byłoby zadaniem niezmiernie trudnym i prowadzącym do skrajnie subiektywnych wniosków (kryterium obiektywności). Co więcej, wnoszenie o lokalizacji danych zjawisk na pode stawie przekazów werbalnych, tym bardziej w ramach przyjętej miejscowej skali analiz, obarczone jest dużym błędem wynikającym chociażby z różnego sposobu formułowania (kodowania werbalnego) informacji geograficznej przez różnych nadawców (np. Mark i in. 1999). Ogólną ocenę dokładności przestrzennej materiałów z kategorii nr 2 podwyższa jednak treść urzędowych map tematycznych, niejednokrotnie bardziej precyzyjnych od treści map PPGIS, opierających się jedynie na subiektywnie formułowanej informacji przestrzennej.

Biorąc pod uwagę pełen proces bonitacji, korzystniej względem odpowiadających im danych wywołanych oceniono następujące cechy materiałów ujętych w kategorii nr 2: ich relatywnie dużą dostępność (szczególnie w odniesieniu do kosztochłonności badań ankietowych i czasochłonności procesów PPGIS), bogatą zasobność (stanowiącą jednak wadę na etapie realizacji celu nr 1, który wymagałby wdrożenia procedur ich systematycznej selekcji) oraz porównywalność czasową, w zasadzie niemożliwą do uzyskania w przypadku reaktywnych badań jakościowych. 
Najwyższą użyteczność w kontekście realizacji analizowanego projektu stwierdzono w odniesieniu do danych liczbowych ujętych w kategorii nr 3 - sumaryczny wynik bonitacji punktowej przyjął wartości dodatnie dla celów szczegółowych nr 1 i 2. Szczególnie w pierwszym z tych przypadków, zadecydowała o tym wyniku nieporównywalnie większa: (1) dostępność danych statystycznych, mierzona niewspółmiernie małym wydatkiem czasu i pieniędzy na uzyskanie oczekiwanych wyników; (2) porównywalność czasowa, będąca odzwierciedleniem istoty statystyki publicznej, zakładającej coroczne ponawianie tych samych badań według identycznej metodyki zbierania danych (np. Kompendium wiedzy... 2012); (3) spójność, wynikająca z jednolitej skali pomiarowej publikowanych danych, a także z możliwości ich agregowania na różnych poziomach szczegółowości przestrzennej analiz; oraz (4) ilość danych, niemożliwa do uzyskania w wyniku przeprowadzenia pojedynczych badań ankietowych. Badacz obierający ten kierunek prac musi jednak mieć na uwadze, że dane zawarte w statystykach publicznych gromadzone są przede wszystkim w odniesieniu do jednostek administracyjnych, co wydatnie utrudnia analizę współzależności występowania określonych cech społecznych w obrębie/otoczeniu innych jednostek przestrzennych, takich jak obszary chronione (kryterium dokładności). Co więcej, statystyki publiczne nie odnoszą się do strukturalnych cech konfliktów społecznych sensu stricto (kryterium obiektywności), choć określenie pewnych założeń (np. wynikających z opisanych w literaturze studiów przypadku innych konfliktów wokół obszarów chronionych) umożliwia zdefiniowanie wskaźników „zastępczych”, skutecznie przybliżających badaną problematykę. Warto też odnotować, że użyteczność danych statystycznych wyraźnie maleje wraz ze zwiększaniem szczegółowości przestrzennej analiz. Wynika to z uzasadnionej przyjętą metodyką (www.stat.gov.pl, dostęp: 28.11.2016) mniejszej kompletności danych na niższych poziomach ich agregacji, wyższego kosztu ich pozyskania (szczególnie w relacji do względnie mało kosztochłonnych wywiadów pogłębionych), a także większego ryzyka nadinterpretacji na etapie doboru wskaźników liczbowych. Sam wynik statystycznej analizy wpływu przyjętych zmiennych trzeba jednak uznać za bardziej obiektywny niż jakościowa interpretacja informacji pozyskanych w drodze przeprowadzanych wywiadów pogłębionych.

\section{Dyskusja}

Choć zaprezentowany przykład ewaluacji użyteczności poszczególnych kategorii danych zastanych dotyczy realizacji konkretnego projektu badawczego, w założeniu praca odnosi się do szerszego zagadnienia obiektywnego doboru metod wykorzystywanych w badaniach geograficznych. Podejście to z powodzeniem może zostać zastosowane choćby do wsparcia decyzji o uwzględnieniu danych zdalnych, 
niepochodzących z bezpośrednich prac terenowych, na poszczególnych etapach badań krajobrazowych ${ }^{5}$. Niezależnie jednak od szczegółowej metody czy przedmiotu oceny zaproponowana filozofia działań wciąż nie jest popularna na etapie planowania zamierzeń badawczych. Tymczasem zaniedbywanie tego kroku może prowadzić do szeregu negatywnych konsekwencji, zarówno o charakterze organizacyjnym, jak i czysto merytorycznym, np. do:

1) obniżenia perspektywy finansowania badań z uwagi na zbyt słabe uzasadnienie zaplanowanych kosztów;

2) nieefektywnego wykorzystania zasobów już będących w dyspozycji badacza (finansowych, czasowych lub osobowych);

3) pokusy traktowania wszystkich analizowanych materiałów jako równoważnych;

4) ograniczenia wartości naukowej pracy ze względu na krytyczną ocenę jedynie tych danych, które podlegają bezpośredniej analizie (klasycznym przykładem może być tu szczegółowa kontrola wiarygodności jedynie tych źródeł, które okazują się wzajemnie sprzeczne).

Dokonany proces ewaluacji potwierdza podkreślane przez Bartkowskiego (1986) i Kostrowickiego (1992) trudności z zapewnieniem pełnego obiektywizmu dokonywanych ocen wartościujących. Jednocześnie procedurę przeprowadzono w sposób ściśle ustrukturyzowany, konsekwentnie podążając za decyzjami i założeniami poczynionymi na wstępnym etapie prac. Jedną z nich było precyzyjne określenie samego zakresu pojęciowego „analizy danych zastanych”. Wbrew sugestiom Frankfort-Nachimas i Nachimasa (2001) wyłączono z niego tzw. analizę śladów czy nieuczestniczącą obserwację naukową, gdyż metody te dotyczą w istocie danych pierwotnych, bezpośrednio mierzonych/interpretowanych przez badacza w ściśle określonym przez siebie celu naukowym. Niektórzy metodolodzy nauk społecznych (Babbie 2013; Maj 2013) sam stopień ingerencji badacza w zawartość analizowanego materiału traktują jako kryterium jego użyteczności, ale autorzy niniejszego opracowania uznali tę cechę za niepodlegającą ocenom różnicującym - stanowi ona bowiem istotę wszystkich źródeł wtórnych. Jednocześnie złożony wątek wpływu badacza na obiektywizm i głębokość zbieranego materiału został uwzględniony w zakresie pojęciowym innych kryteriów.

Niejednoznaczność wartościowania stopnia ingerencji badacza w zawartość analizowanego materiału wynika ze swoistej suplementarności metod ilościowych i jakościowych. Zastosowanie tych pierwszych, z założenia obiektywnych, wpływa na zwiększenie rzetelności badań, zazwyczaj jednak kosztem ich trafności (Babbie 2013). Wykorzystane studium przypadku, uwzględniające mieszane tryby podejść do zbierania danych (ang. mixed-mode approach; Creswell 2013), umożliwiło zaprezentowanie potencjalnego wpływu specyfiki obu grup metod na interpretację dobranych

\footnotetext{
${ }^{5}$ Problematyka ta została szeroko rozwinięta w opracowaniu Balona i in. (2015).
} 
kryteriów. Szczególnego omówienia wymaga w tym kontekście kryterium obiektywności danych, zupełnie inaczej interpretowanej w ramach ilościowego i jakościowego modelu badań (Kvale 2004). Mając na uwadze te różnice, na etapie doboru zakresu pojęciowego kryteriów oceny, obiektywność danych powiązano z kwestią ryzyka ich nadinterpretacji. W konsekwencji automatycznie wzmocniona została wartość materiałów jakościowych uzyskiwanych z wykorzystaniem metod reaktywnych zawsze dają one badaczowi możliwość bieżącego pogłębiania wątków, które wydają mu się niejasne, podczas gdy źródła wtórne oferują jedynie zastaną treść przekazu.

Inną konsekwencją rozszerzenia zakresu pojęciowego obiektywności danych było swoiste wzmocnienie znaczenia tego kryterium względem pozostałych. W wielu przypadkach właśnie na płaszczyźnie obiektywności (czasami też - dokładności) danych dokonywano rzeczywistej oceny wstępnej, czy zawartość merytoryczna ocenianego materiału umożliwia zrealizowanie danego celu szczegółowego projektu. Konsekwentnie stosowano jednak dwie zasady: (1) ostrożnego używania wartości „zerujących”; oraz (2) niestosowania wag w odniesieniu do wykorzystywanych kryteriów. W pierwszym przypadku kierowano się spostrzeżeniem Hymana (1987, za: Frankfort-Nachimas, Nachimas 2001), który podkreślił pozytywne aspekty wykorzystywania danych niedotyczących wprost analizowanego zagadnienia badawczego: badacz jest wówczas zmuszony do szerszego spojrzenia na podejmowaną problematykę, a równoległy dobór wielu uzupełniających się wskaźników paradoksalnie może uczynić proces badawczy bardziej wyczerpującym. Oczywiście podejście to wymaga od realizującego projekt znacznie większej ostrożności, a niejednokrotnie - dużego doświadczenia naukowego, co wpłynęło na obniżenie końcowej oceny użyteczności niektórych źródeł, ale nie decydowało o ich dyskwalifikacji.

Druga z przyjętych zasad, dotycząca rezygnacji ze stosowania wag, spowodowana była chęcią zminimalizowania subiektywizmu całego procesu oraz podkreślenia roli złożoności pełnego wachlarza kryteriów, które wpływają na końcową ocenę użyteczności badanych źródeł. Kontrowersje mogłaby bowiem wzbudzać nie tylko sama wartość wag, ale i dobór uprzywilejowanych kryteriów - oprócz wzmocnienia kryterium obiektywności przedmiotem debaty mogłoby być np. kryterium dostępności źródeł, które każdorazowo proporcjonalnie traci na znaczeniu wraz ze wzrostem możliwości budżetowych danego projektu badawczego.

$\mathrm{Z}$ metodycznego punktu widzenia za najbardziej wymagający należy uznać proces ewaluacji użyteczności źródeł ujętych w wyjątkowo pojemnej kategorii nr 2. Niewątpliwie sama decyzja o nierozdzielaniu tak zróżnicowanego zbioru obiektów wpłynęła na jego negatywne oceny względem kryterium spójności danych, a także innych, powiązanych z powyższym. Jednocześnie stopień rozproszenia informacji dotyczących strukturalnych cech konfliktów społecznych w treści omawianych przekazów jest tak duży, że jedynie łączne wykorzystanie wielu ich rodzajów daje perspektywy realizacji na ich podstawie poszczególnych celów szczegółowych analizowanego 
projektu. $Z$ technicznego punktu widzenia rozdzielenie zbioru obiektów w ramach kategorii nr 2 oznaczałoby zatem konieczność przypisania im wartości „zerujących” względem kryterium dokładności materiałów.

Innym problemem związanym z oceną użyteczności materiałów z kategorii nr 2 było ryzyko błędnego ustalenia rzeczywistego przedmiotu analizy treści wykonywanej na ich podstawie. W ujęciu dosłownym metoda ta pozwala na wyciąganie wniosków dotyczących pojawień się konkretnych przekazów społecznych (Babbie 2013), a trafne przeniesienie poziomu analiz z płaszczyzny komunikatu na wymiar faktów i realnych zjawisk zazwyczaj wymaga posiłkowania się szeroką wiedzą, także pochodzącą z badań reaktywnych. Przykładem obrazującym możliwe konsekwencje zbyt silnego zaufania do materiału zastanego może być uznanie danej formy ochrony przyrody za niewpływającą na strukturę lokalnych konfliktów społecznych tylko ze względu na brak zgromadzonych przekazów przeczących tej tezie. Za każdym razem formułowanie tak mocnego stanowiska, niepopartego uprzednią jego weryfikacją „w terenie”, należy uznać za dalece ryzykowne, co znalazło odzwierciedlenie w wartościach ocen dotyczących obiektywności omawianych danych. Co więcej, na przyznane oceny wiarygodności danych ujętych w kategorii nr 2 wpłynęło też konsekwentne uznawanie poszczególnych celów szczegółowych projektu za podstawę analizy treści. W przypadku gdyby rzeczywistej analizie podlegał sam przekaz, ocena jego wiarygodności mogłaby wręcz stanowić istotę całych badań (Makowska, Boguszewski 2013), jednak w niniejszym przypadku trzeba ją uznać wyłącznie za kryterium obniżające użyteczność analizowanych materiałów w kontekście omawianego projektu.

Zarysowana złożoność przedstawionego procesu ewaluacji sugeruje, że przekładanie jego wyników na etap realizacji projektu badawczego nie powinno ograniczać się do prostego wykorzystania końcowych wartości uzyskanych w toku bonitacji punktowej. Jak wynika z zaprezentowanego przykładu, nawet pozytywna ocena użyteczności danych statystycznych w kontekście realizacji celów szczegółowych nr 1 i 2 obarczona została pewnymi zastrzeżeniami, dotyczącymi m.in. dokładności i obiektywności tych źródeł. $Z$ aplikacyjnego punktu widzenia idealnym rozwiązaniem, choć uwarunkowanym możliwościami organizacyjnymi danego zamierzenia badawczego, wydaje się wykorzystanie danych wtórnych uznanych za użyteczne w charakterze wsparcia dla wyników badań reaktywnych odpowiadających na ten sam cel szczegółowy (por. Frankfort-Nachimas, Nachimas 2001). Co więcej, brak konieczności rezygnowania z badań reaktywnych umożliwia dokooptowanie do schematu badawczego także analizy tych danych, które uzyskały nieznacznie negatywny wynik bonitacji. W przypadku omawianego projektu zdecydowano się na taki zabieg w odniesieniu do źródeł z kategorii nr 2 (w kontekście realizacji celu szczegółowego nr 2). Uznano, że proces jakościowej analizy treści, zmierzający do budowania modeli powiązań wyodrębnionych elementów przekazu (Maj 2013) doskonale koresponduje $\mathrm{z}$ planowanym w badaniach modelowaniem strukturalnych 
cech konfliktów na podstawie wyników przeprowadzonych wywiadów pogłębionych. Co znamienne, sam proces opracowywania obu grup materiałów nie różni się istotnie w wymiarze technicznym - podlegające uprzedniej transkrypcji treści wywiadów również stanowić będą przedmiot kodowania, kategoryzacji i modelowania znaczeniowego (Babbie 2013).

Ostrożna interpretacja metrycznego wyniku bonitacji koresponduje z poglądem Bartkowskiego (1986) przestrzegającego przed traktowaniem wartości punktowych jako miar obiektywnych oraz podkreślającego znaczenie samej struktury kryteriów, które złożyły się na końcową ocenę. Tak rozumiany walor aplikacyjny bonitacji punktowej przyznaje tej technice wyższość nad bardziej opisowymi metodami wspierania decyzji, jak np. analiza SWOT (Bowman 1990) lub drzewa decyzyjnego (LaRaus, Remy 1978), niewymagającymi każdorazowego odnoszenia się badacza do identycznie zdefiniowanych kryteriów oceny.

\section{Wnioski}

1. Dokonywanie systematycznej oceny użyteczności szerokiego spectrum dostępnych danych do realizacji poszczególnych celów projektów badawczych powinno stanowić jedno z podstawowych zadań na etapie planowania badań naukowych.

2. Potwierdzono skuteczność techniki bonitacji punktowej do realizacji powyższych celów. Jej podstawowymi zaletami są: konieczność każdorazowego odnoszenia się analityka do przyjętych kryteriów oceny oraz możliwość czytelnego prześledzenia struktury końcowego wyniku ewaluacji. Nie bez znaczenia wydaje się również dobra znajomość tej techniki wśród geografów ze względu na jej dużą popularność w kontekście ocen krajobrazu.

3. Pozytywny metryczny wynik bonitacji punktowej w zakresie użyteczności danych zastanych do realizacji poszczególnych celów badawczych należy traktować jako wskazówkę do podjęcia decyzji o włączeniu analizy tych źródeł do aparatu metodycznego projektu. Ostateczny wybór powinien być uzależniony od możliwości organizacyjnych planowanych badań. Do całkowitego wykluczenia części badań reaktywnych należy się skłaniać w odniesieniu do zamierzeń niskobudżetowych (por. Makowska 2013), aw sytuacji idealnej proponowane jest włączenie obu grup metod do struktury projektu.

4. Podejmowanie ogólnej oceny użyteczności danych zastanych w kontekście projektów naukowych o rozbudowanej strukturze, złożonej metodyce i wieloaspektowej warstwie merytorycznej należy uznać za niewystarczające. Potwierdza to duże zróżnicowanie ocen tych samych kategorii źródeł wtórnych uzyskanych dla poszczególnych celów szczegółowych analizowanego zamierzenia badawczego. Każde studium przypadku może przynieść istotne uzupełnienie w stosunku 
do powszechnie formułowanych sądów natury ogólnej na temat wad i korzyści stosowania źródeł wtórnych w procesach badawczych (np. Frankfort-Nachimas, Nachimas 2001; Babbie 2013; Maj 2013; Makowska 2013).

5. W związku z negatywnym wynikiem bonitacji punktowej względem opublikowanego już dorobku naukowego, potwierdzono zasadność podjęcia tematu relacji pomiędzy obszarową formą ochrony przyrody a strukturalnymi i przestrzennymi cechami konfliktów w obrębie systemów społeczno-ekologicznych obszarów chronionych województwa małopolskiego.

\section{Literatura}

Babbie E., 2013, Podstawy badań spotecznych, Wydawnictwo Naukowe PWN, Warszawa.

Balon J., 2002, Regionalne wróżnicowanie konfliktów čtowiek-środowisko na obsæarze Tatræańskiego Parku Narodowego, [w:] J. Partyka (red.), U̇̇ytkowanie turystyczne parków narodowych. Ruch turystyczny - sagospodarowanie - konflikty - zagrożenia, Instytut Ochrony Przyrody PAN, Ojcowski Park Narodowy, Ojców, 715-722.

Balon J., Maciejowski W., 2012, Geoekologia dla architektów krajobrazu, Instytut Architektury Krajobrazu PK, Kraków.

Balon J., Krąż P., Mocior E., Rechciński M. (red.), 2015, Rola badań terenowych w studiach krajobrazowych XXI wieku, PAEK, IGiGP UJ, Warszawa-Kraków.

Bartkowski T., 1986, Zastosowania geografii fizycznej, Wydawnictwo Naukowe PWN, Warszawa.

Bednarowska Z., 2005, Desk research - wykorzystanie potencjatu danych sastanych w prowadzeniu badań marketingowych i spotecznych, Marketing i Rynek, 7, 18-26.

Bowman C., 1990, The Essence of Strategic Management, Prentice Hall, Hemel Hempstead.

Brocke J. vom, Lippe S., 2010, Taking a project management perspective on design science research, [w:] International conference on design science research in information systems, Springer, BerlinHeidelberg, 31-44.

Brown G., Raymond C.M., 2014, Methods for identifying land use conflict potential using participatory mapping, Landscape and Urban Planning, 122, 196-208.

Bródka S., 2010, Etapy oceny środowiska præyrodnicæego w ujęciu praktyčnym, [w:] S. Bródka (red.), Praktyczne aspekty ocen środowiska przyrodniczego, Bogucki Wydawnictwo Naukowe, Poznań, 27-50.

Creswell J.W., 2013, Projektowanie badań naukowych. Metody jakościowe, ilościowe i mieszane, Wydawnictwo Uniwersytetu Jagiellońskiego, Kraków.

Frankfort-Nachimas C., Nachimas D., 2001, Metody badawcze w naukach spotecznych, Zysk i S-ka, Poznań.

Główny Urząd Statystyczny, Portal Informacyjny, http://stat.gov.pl/obszary-tematyczne/ ludnosc/ludnosc/informacja-o-dostepnosci-danych-dotyczacych-osob-niepelnosprawnychna-poziomie-wojewodztw-powiatow-i-gmin,15,1.html (28.11.2016). 
Grodzińska-Jurczak M., Cent J., 2011, Expansion of nature conservation areas: Problems with Natura 2000 implementation in Poland?, Environmental Management, 47 (1), 11-27.

Hellström E., 2001, Conflict cultures: Qualitative comparative analysis of environmental conflicts in forestry, The Finnish Society of Forest Science, The Finnish Forest Research, Helsinki.

Hibszer A., 2004, Aktualne konflikty cztowiek-przyroda w karpackich parkach narodowych, Prace Komisji Krajobrazu Kulturowego PTG, 3, 193-209.

Hibszer A., 2013, Parki narodowe w świadomości i działaniach spoteczności lokalnych, Uniwersytet Śląski, Katowice.

Hibszer A., Partyka J. (red.), 2005, Między ochronq przyrody a gospodarkq - bliżej ochrony. Konflikty cztowiek-przyroda w obszarach prawnie chronionych w Polsce, Oddział Katowicki PTG, Ojcowski Park Narodowy, Sosnowiec-Ojców.

Hyman H.H., 1987, Secondary Analysis of Sample Surveys, Wesleyan University Press, Middletown, Conn.

Kompendium wiedzy z jakości w statystyce publicznej. Materiaty dla odbiorcy zewnętr:nego, 2012, Urząd Statystyczny w Łodzi, Ośrodek Statystyki Matematycznej przy współpracy z Departamentem Metodologii, Standardów i Rejestrów GUS, Warszawa.

Kostrowicki A.S., 1992, System „čłowiek-środowisko” w świetle teorii ocen, Ossolineum, Wrocław.

Królikowska K., 2007, Konflikty spoteczne w polskich parkach narodowych, Oficyna Wydawnicza „Impuls”, Kraków.

Kucina W., 2007, Konflikt spotecæny na tle wtasności gruntów w Tatrzańskim Parku Narodowym, Acta Universitatis Lodziensis, Folia Geographica Socio-Oeconomika, 8, 185-210.

Kvale S., 2004, InterViews. Wprowadzenie do jakościowego wywiadu badawczego, Wydawnictwo Uniwersyteckie Trans-Humana, Białystok.

LaRaus R., Remy R.C., 1978, Citiæenship decision-making: Skills activities and materials, Addison-Wesley, Reading, Mass.

Narodowe Centrum Nauki, https://www.ncn.gov.pl/finansowanie-nauki/konkursy (28.11.2016).

Mace G.M., 2014, Whose conservation?, Science, 345 (6204), 1558-1560.

Maj A., 2013, Analiza treści, [w:] M. Makowska (red.), Analiza danych sastanych. Præewodnik dla studentów, Wydawnictwo Naukowe Scholar, Warszawa, 127-147.

Makowska M., 2013, Desk Research, [w:] M. Makowska (red.), Analiza danych sastanych. Przewodnik dla studentów, Wydawnictwo Naukowe Scholar, Warszawa, 80-103.

Makowska M., Boguszewski R., 2013, Analiza danych sastanych - sagadnienia wstepne, [w:] M. Makowska (red.), Analiza danych zastanych. Præewodnik dla studentów, Wydawnictwo Naukowe Scholar, Warszawa, 9-31.

Mark D.M., Freksa C., Hirtle S.C., Lloyd R., Tversky B., 1999, Cognitive models of geographical space, International Journal of Geographical Information Science, 13 (8), 747-774.

Palomo I., Montes C., Martín-López B., González J.A., García-Llorente M., Alcorlo P., Mora M.R.G., 2014, Incorporating the social-ecological approach in protected areas in the Anthropocene, BioScience, 64 (3), 181-191.

Pieter J., 1967, Ogólna metodologia pracy naukowej, Ossolineum, Wrocław. 
Pietrzyk-Kaszyńska A., Rechciński M., Olszańska A., Mączka K., Matczak P., Niedziałkowski K., Cent J., Peek B., Grodzińska-Jurczak M., 2016, Ustugi ekosystemów na obszarach cennych przyrodniczo z perspektywy różnych grup interesariuszy, Instytut Ochrony Przyrody PAN, Kraków.

Rechciński M., 2012, Diagnoza historycznych sytuacji konfliktotwórczych w parkach narodowych na przyktadzie Gorczańskiego Parku Narodowego, Problemy Ekologii Krajobrazu, 33, 135-143.

Rozporządzenie Rady Ministrów z dnia 27 sierpnia 2014 r. w sprawie programu badań statystycznych statystyki publicznej na rok 2015, Dz.U. 2014 poz. 1330.

Sołowiej D., 1987, Podstawy metodyki oceny środowiska przyrodniczego cztowieka, Wydawnictwo Naukowe UAM, Poznań.

Sułek A., 2002, Ogród metodologii socjologicznej, Wydawnictwo Naukowe Scholar, Warszawa. Sztumski J., 2010, Wstęp do metod i technik badań spotecznych, wyd. 7, „Śląsk”, Katowice.

Świderek K., 2013, Źródła danych zastanych, [w:] M. Makowska (red.), Analiza danych :astanych. Præewodnik dla studentów, Wydawnictwo Naukowe Scholar, Warszawa, 32-54.

Ustawa z dnia 29 czerwca 1995 r. o statystyce publicznej, Dz.U. 1995 nr 88 poz. 439.

Wawrzyńczak R., 1981, O ocenach i ocenianiu, Prakseologia, 3 (79), 5-14.

White R.M., Fischer A., Marshall K., Travis J.M., Webb T.J., Di Falco S., Redpath S., Wal R. van der, 2009, Developing an integrated conceptual framework to understand biodiversity conflicts, Land Use Policy, 26 (2), 242-253.

Wojciechowski K.H., 1986, Problemy percepcji i oceny estetycznej krajobrazu, Wydawnictwo UMCS, Lublin.

\author{
Marcin Rechcinski \\ Uniwersytet Jagiellonski \\ Instytut Geografii i Gospodarki Przestrzennej \\ ul. Gronostajowa 7, 30-387 Krakow \\ marcin.rechcinski@doctoral.uj.edu.pl \\ Jarostaw Balon \\ Uniwersytet Jagielloński \\ Instytut Geografii i Gospodarki Przestrzennej \\ ul. Gronostajowa 7, 30-387 Kraków \\ jaroslaw.balon@uj.edu.pl \\ Matgorzata Grodzinska-Jurczak \\ Uniwersytet Jagielloński w Krakowie \\ Instytut Nauk o Środowisku \\ ul. Gronostajowa 7, 30-387 Kraków \\ m.grodzinska-jurczak@uj.edu.pl
}




\begin{tabular}{|c|c|c|c|c|c|c|}
\hline & & 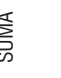 & 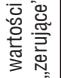 & & $P$ & \\
\hline & & $\begin{array}{l}\text { 品 } \\
\text { 产 } \\
\text { 兽 } \\
\text { 言 }\end{array}$ & 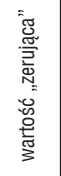 & 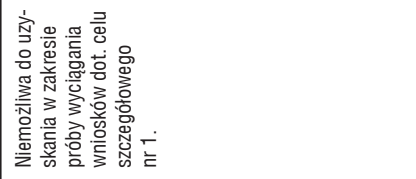 & $\sim$ & 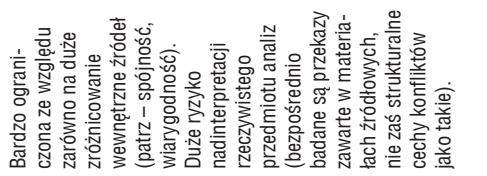 \\
\hline & & 兑 & 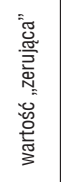 & 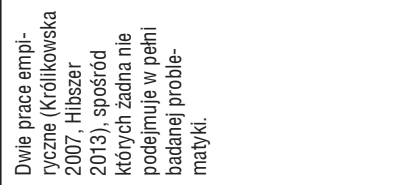 & $T$ & 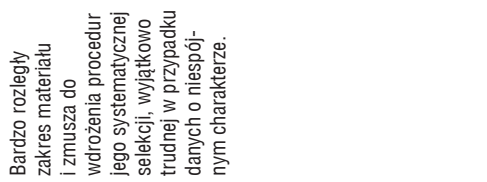 \\
\hline 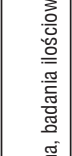 & & \begin{tabular}{l} 
品 \\
言 \\
言 \\
o. \\
\multirow{3}{3}{}
\end{tabular} & 0 & 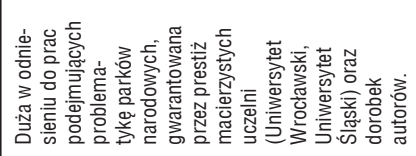 & 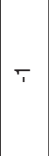 & 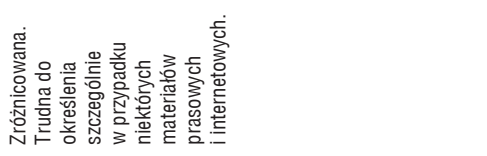 \\
\hline 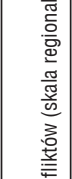 & & $\begin{array}{l}\text { 品 } \\
\text { 言 } \\
\text { 总 }\end{array}$ & 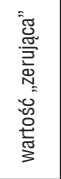 & 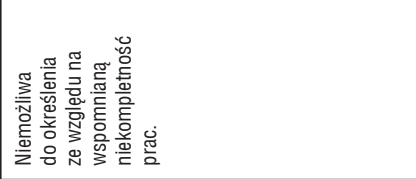 & $\sim$ & 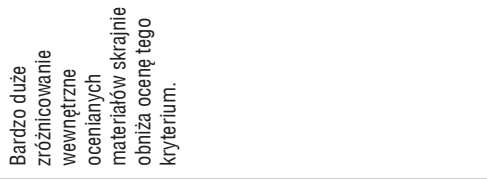 \\
\hline 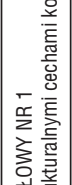 & 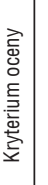 & 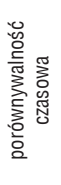 & 0 & 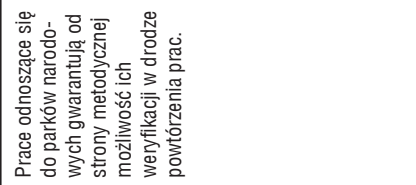 & - & 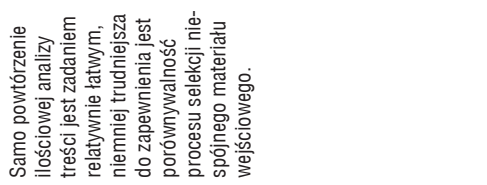 \\
\hline 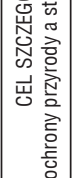 & & 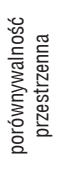 & - & 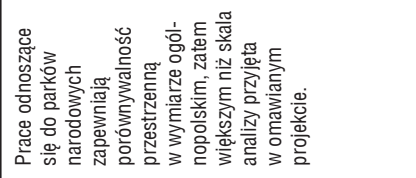 & $\sim$ & 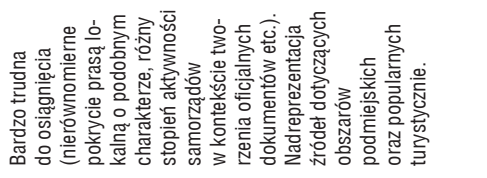 \\
\hline 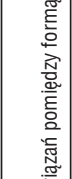 & & 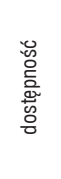 & 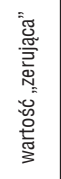 & 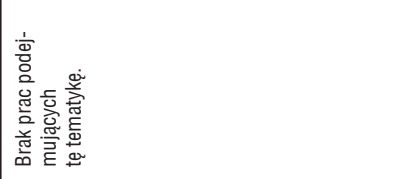 & 0 & 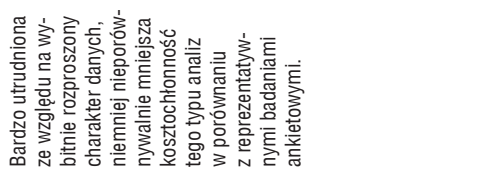 \\
\hline 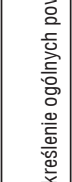 & & 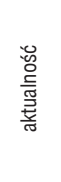 & 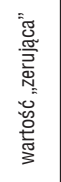 & 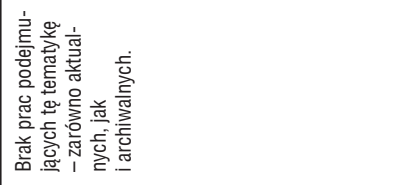 & $T$ & 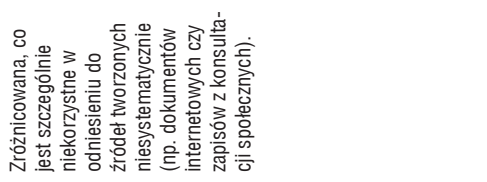 \\
\hline & & 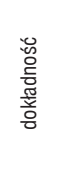 & 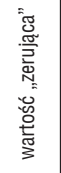 & 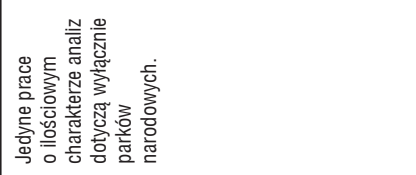 & 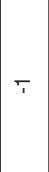 & 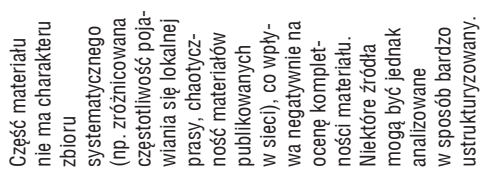 \\
\hline & & 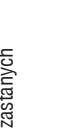 & $\begin{array}{l}\text { 嵒 } \\
\text { 。 }\end{array}$ & 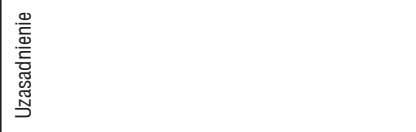 & 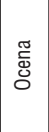 & 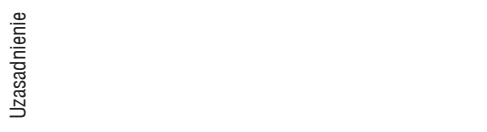 \\
\hline & & (ָ) & & 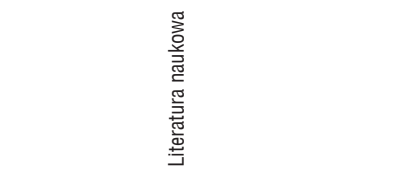 & & 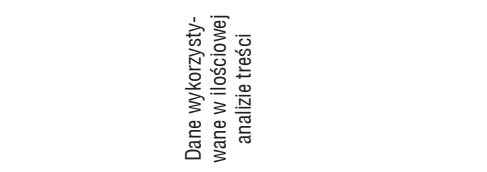 \\
\hline
\end{tabular}




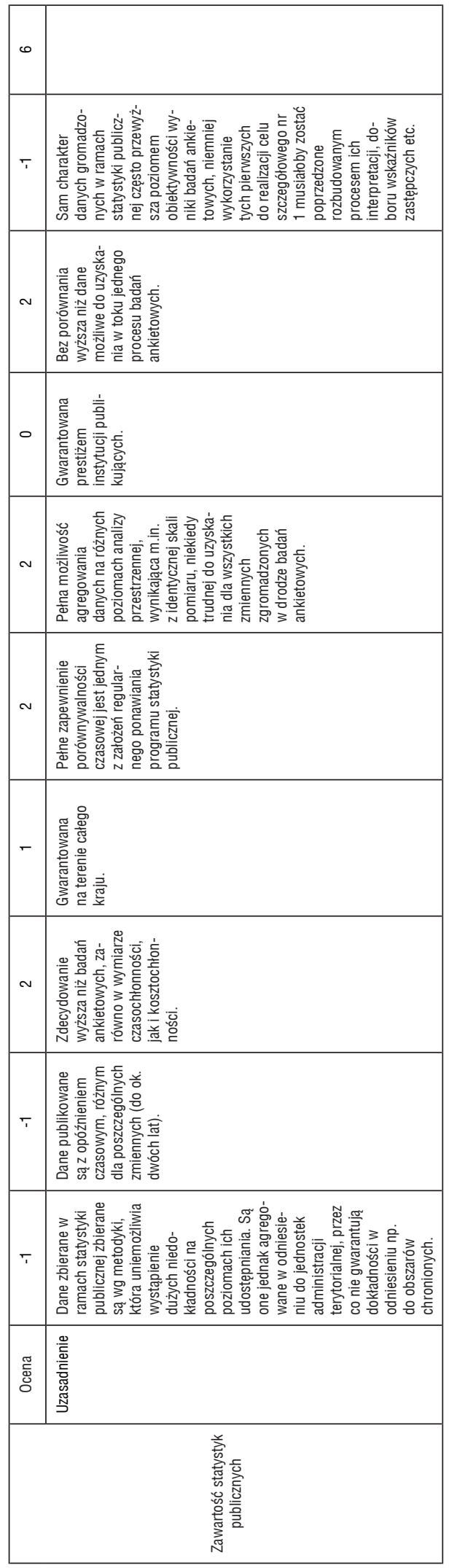




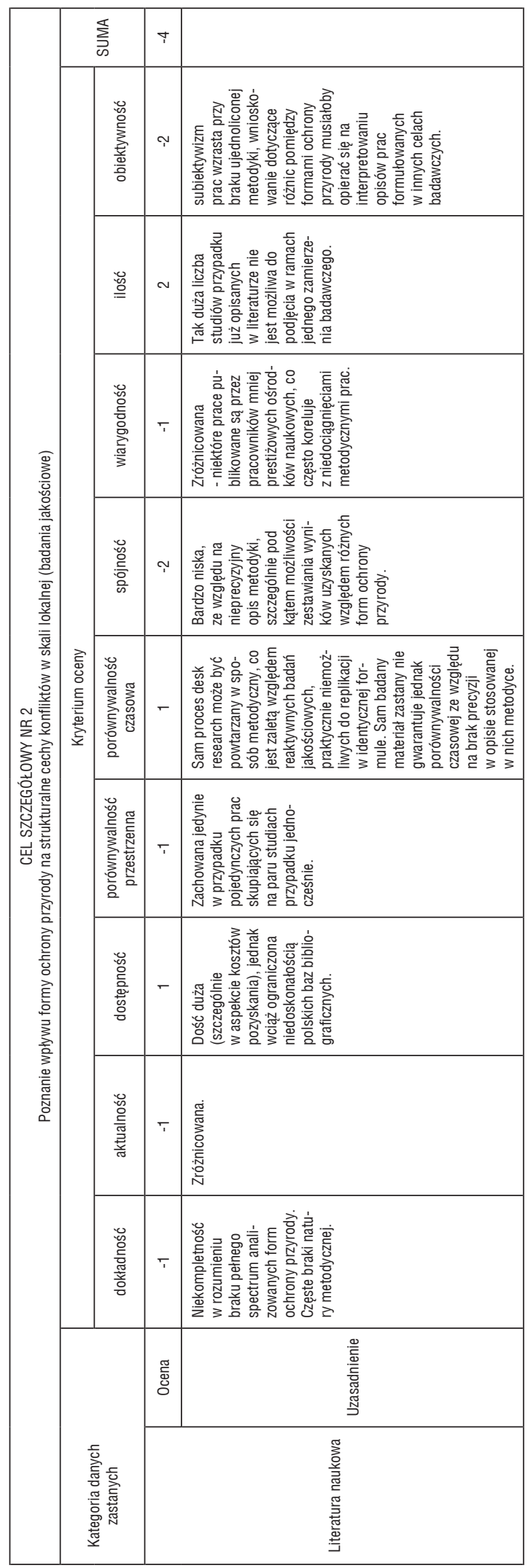




\begin{tabular}{|c|c|c|c|}
\hline$\sim$ & & m & \\
\hline$\sim$ & 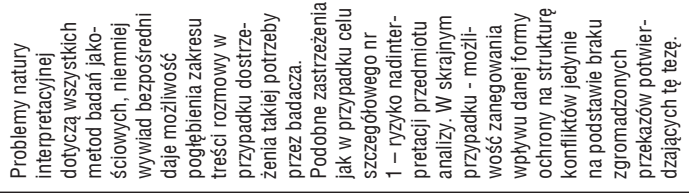 & 0 & 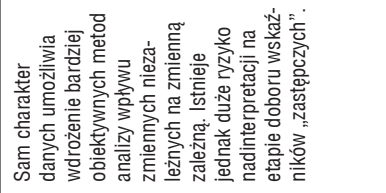 \\
\hline$\sim$ & 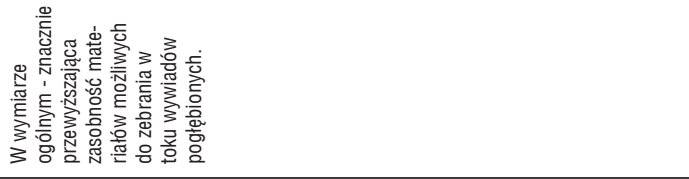 & $\sim$ & 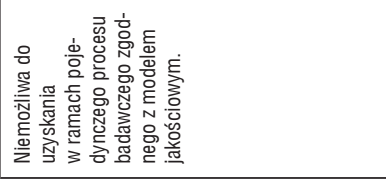 \\
\hline $\bar{T}$ & 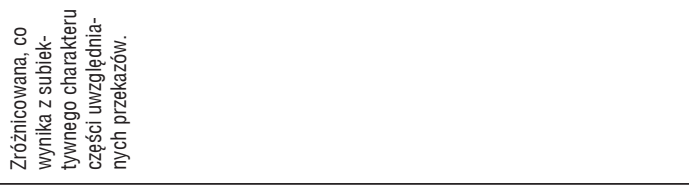 & 0 & 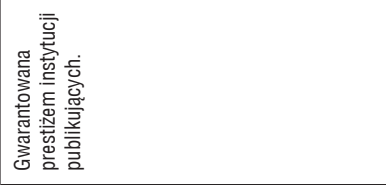 \\
\hline $\bar{T}$ & 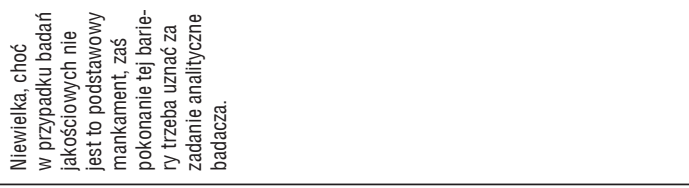 & $\sim$ & 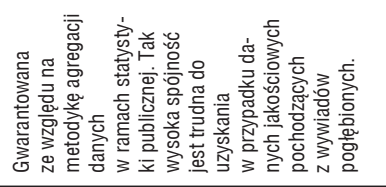 \\
\hline$\sim$ & 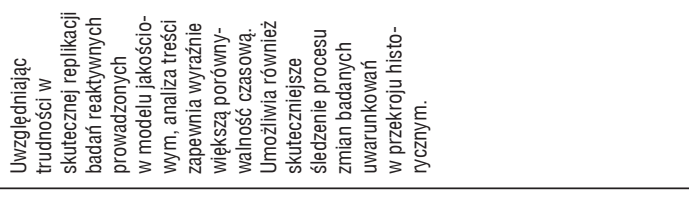 & $\sim$ & 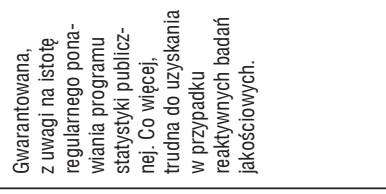 \\
\hline $\bar{T}$ & 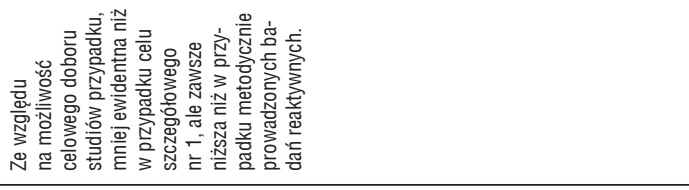 & - & 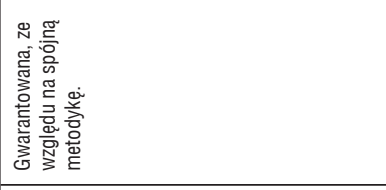 \\
\hline 0 & 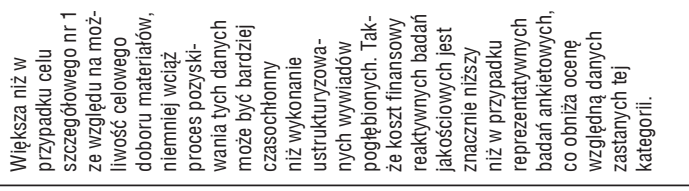 & $\bar{T}$ & 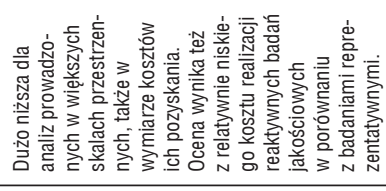 \\
\hline 0 & 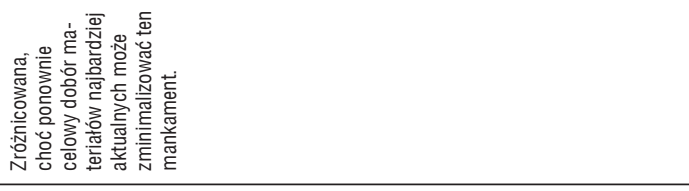 & $T$ & 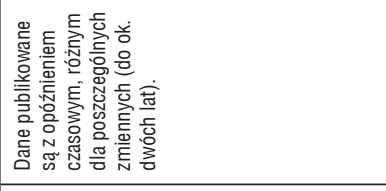 \\
\hline 0 & 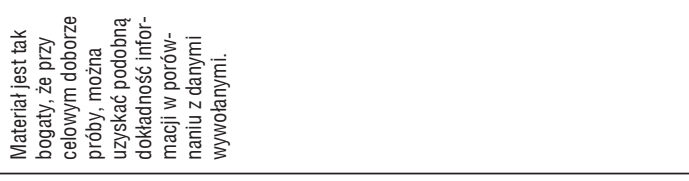 & $\sim$ & 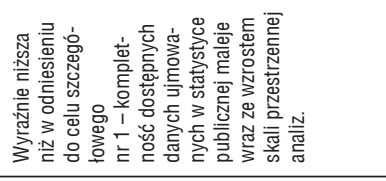 \\
\hline 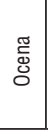 & 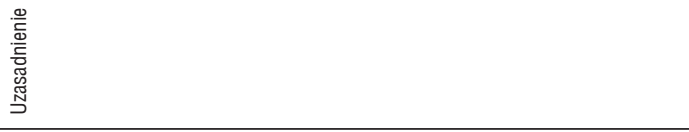 & 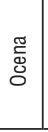 & 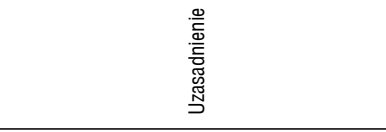 \\
\hline & 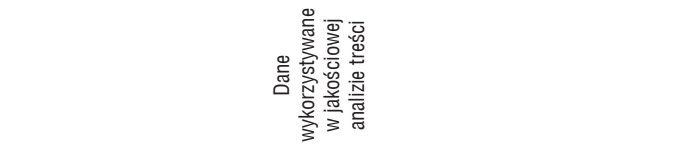 & & 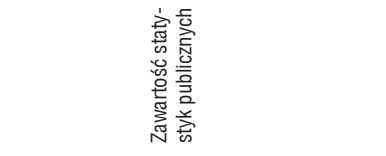 \\
\hline
\end{tabular}




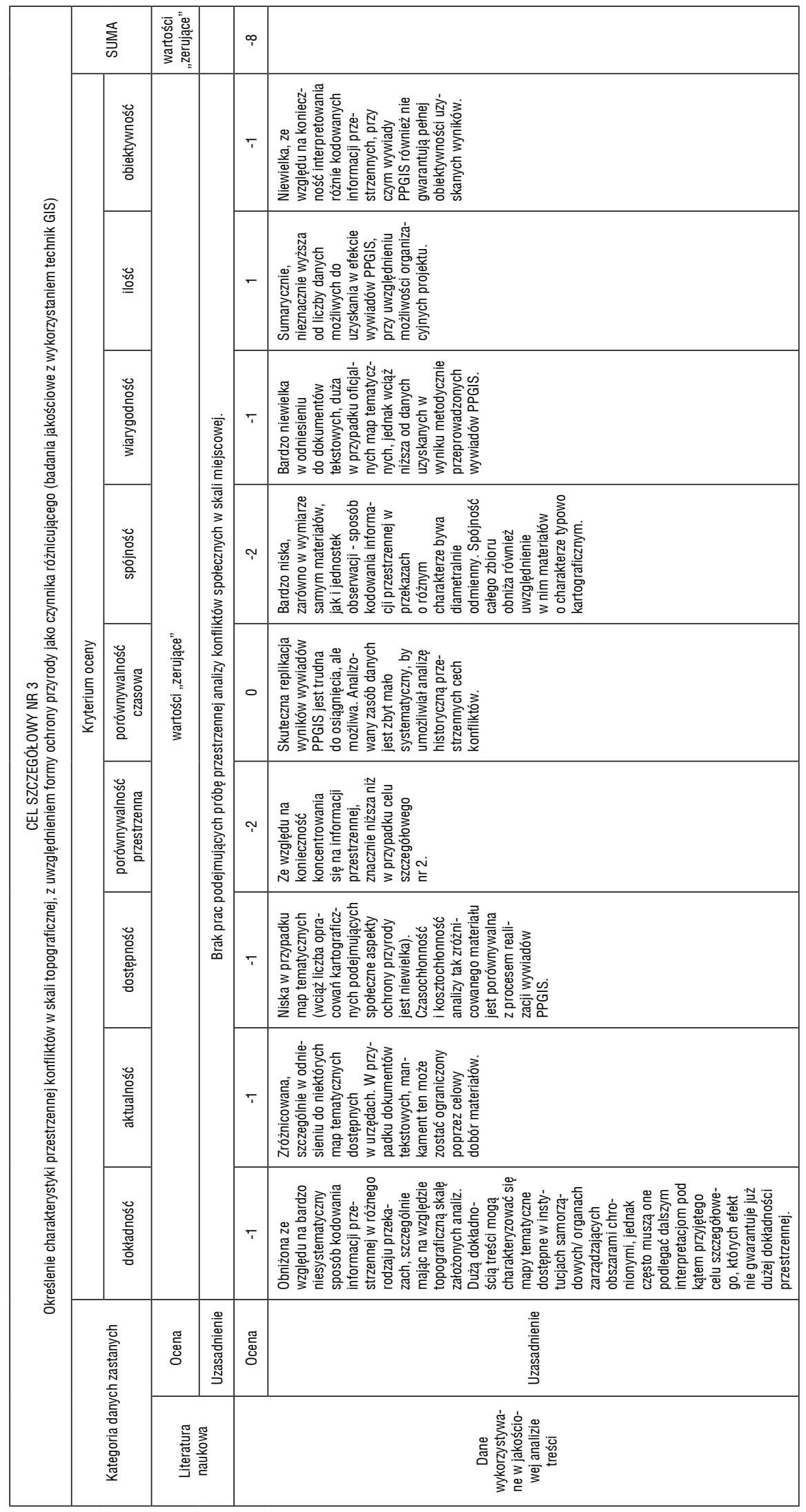




\begin{tabular}{|c|c|}
\hline 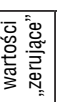 & \\
\hline 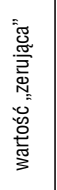 & 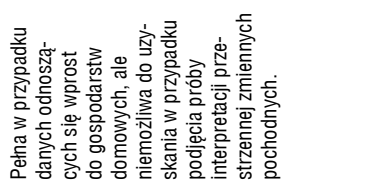 \\
\hline- & 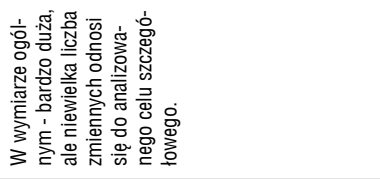 \\
\hline$T$ & 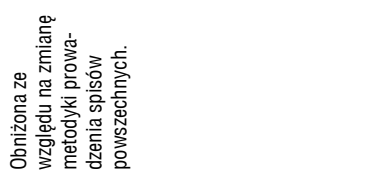 \\
\hline$\sim$ & 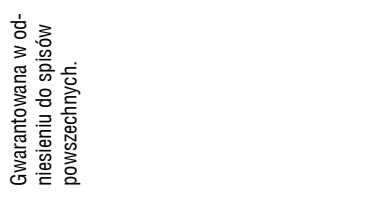 \\
\hline 0 & 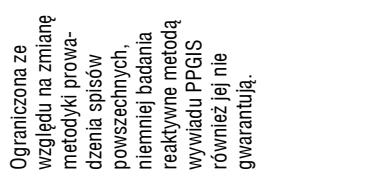 \\
\hline 0 & 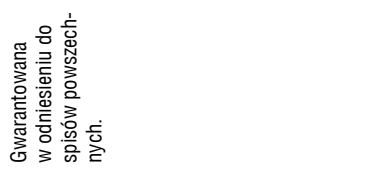 \\
\hline 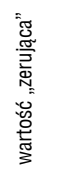 & 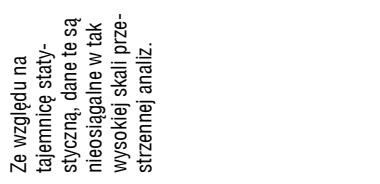 \\
\hline$\Upsilon$ & 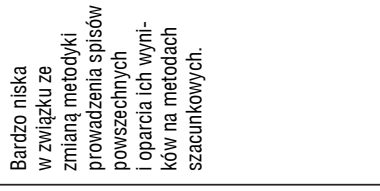 \\
\hline 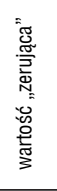 & 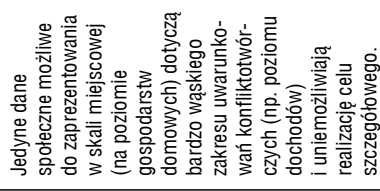 \\
\hline 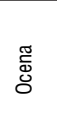 & 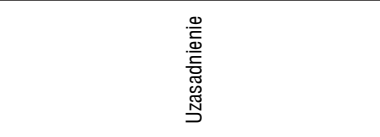 \\
\hline & 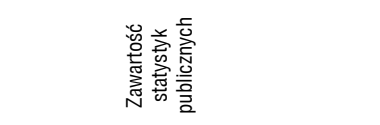 \\
\hline
\end{tabular}




\begin{tabular}{|c|c|c|c|c|c|c|}
\hline & 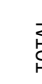 & & 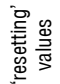 & & 9 & \\
\hline & & 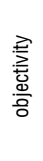 & 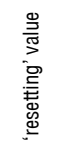 & 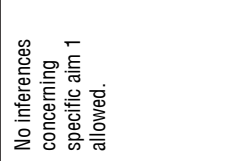 & $\sim$ & 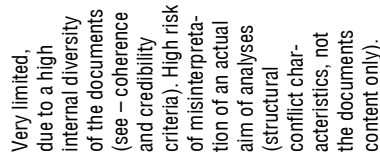 \\
\hline & & $\begin{array}{l}\text { 壳 } \\
\text { 言 } \\
\text { 焉 }\end{array}$ & 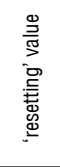 & 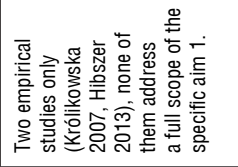 & $T$ & 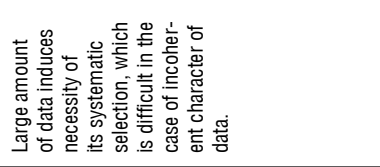 \\
\hline 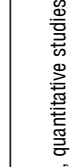 & & $\begin{array}{l}\text { 訔 } \\
\text { 言 } \\
\text { 曾 }\end{array}$ & 0 & 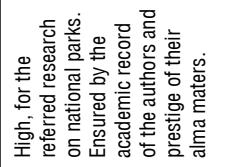 & $T$ & 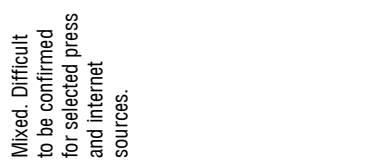 \\
\hline 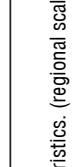 & & 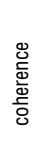 & 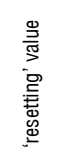 & 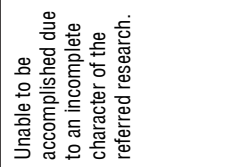 & $\sim$ & 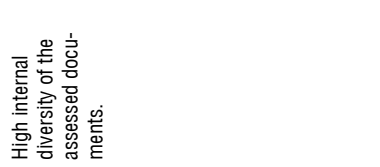 \\
\hline 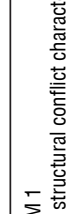 & 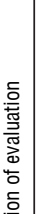 & 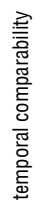 & 0 & 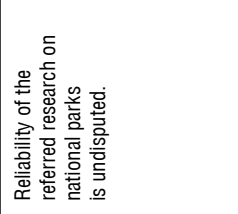 & - & 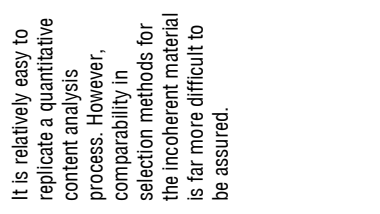 \\
\hline 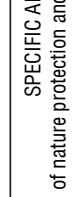 & 売 & 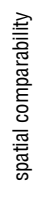 & - & 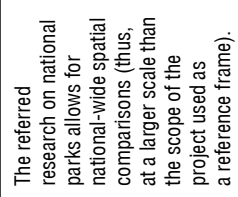 & $\sim$ & 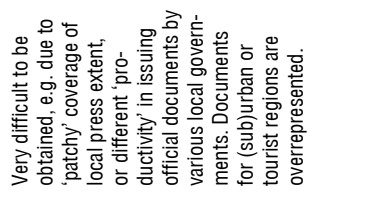 \\
\hline 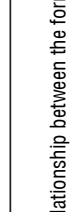 & & 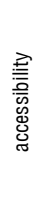 & 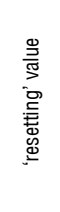 & 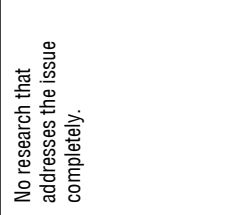 & 0 & 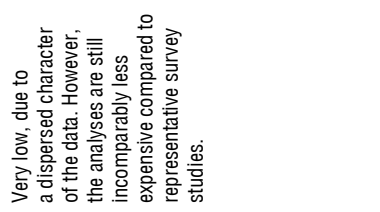 \\
\hline 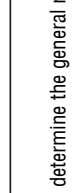 & & 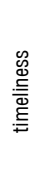 & 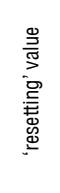 & 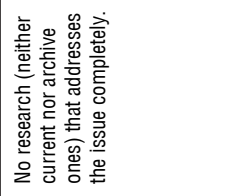 & T & 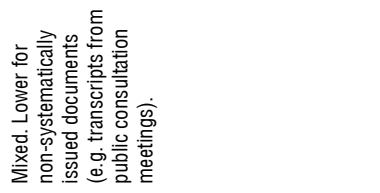 \\
\hline & & $\begin{array}{l}\text { 产 } \\
\text { 总 }\end{array}$ & 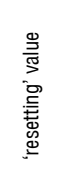 & 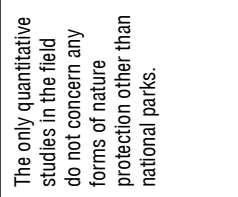 & $T$ & 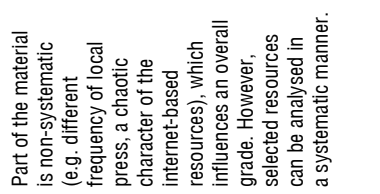 \\
\hline & 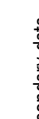 & & 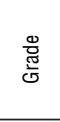 & 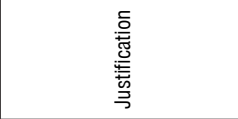 & 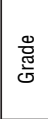 & 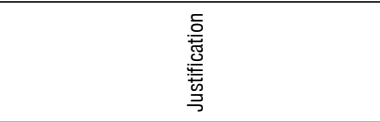 \\
\hline & c & & & 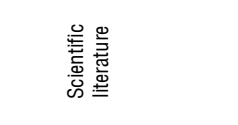 & & 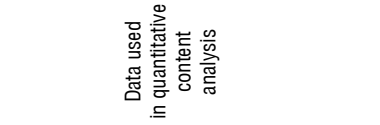 \\
\hline
\end{tabular}




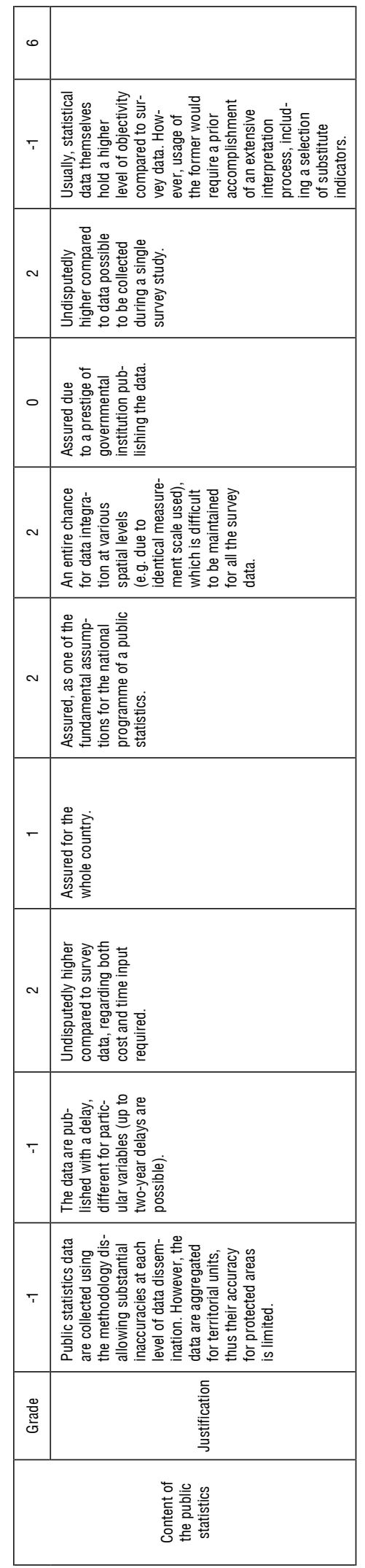




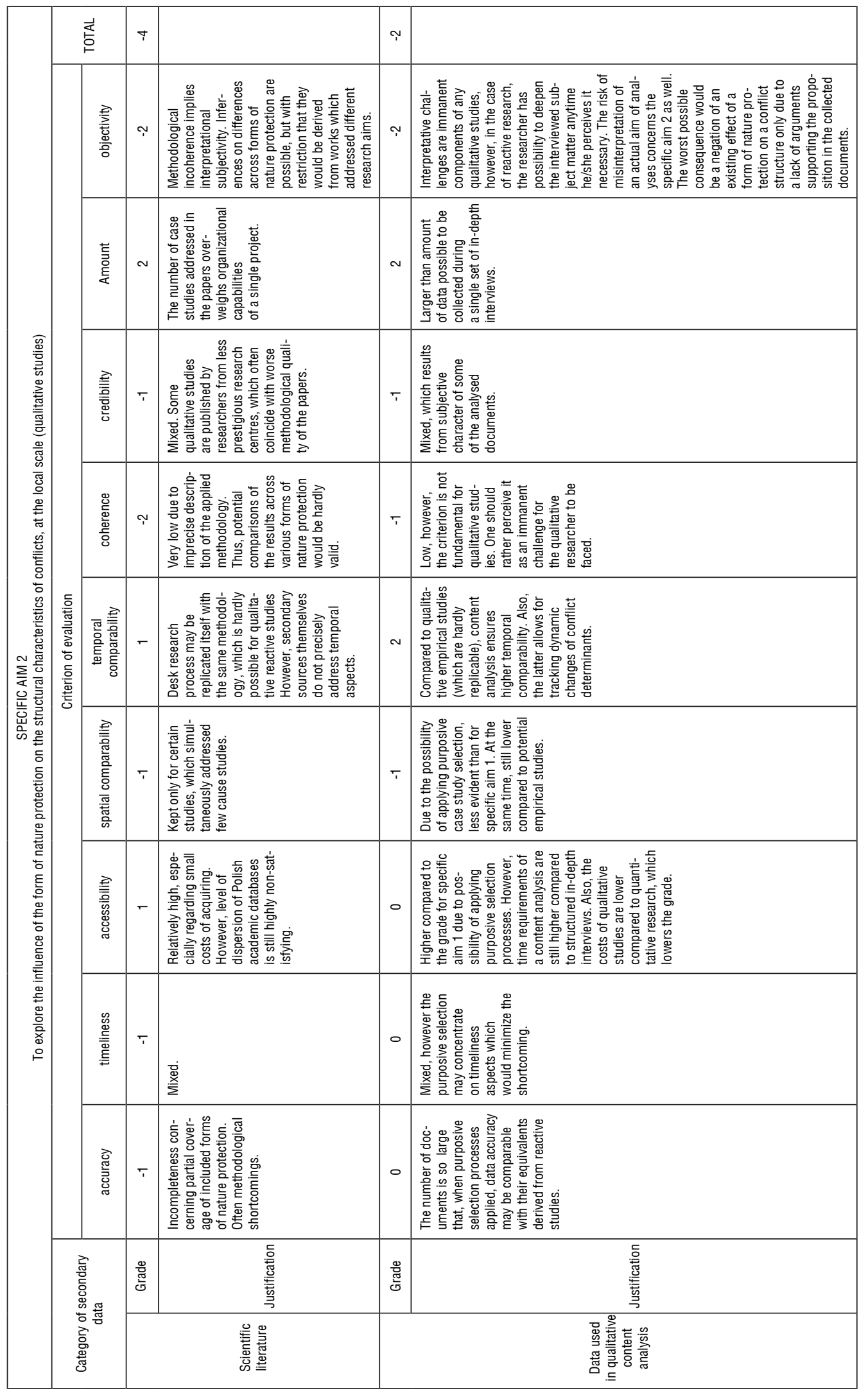




\begin{tabular}{|c|c|}
\hline$m$ & \\
\hline 0 & 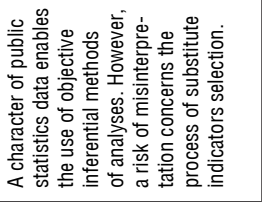 \\
\hline$\sim$ & 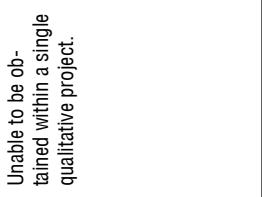 \\
\hline 0 & 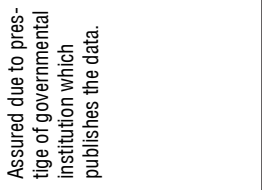 \\
\hline$\sim$ & 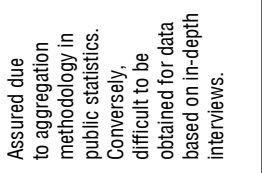 \\
\hline$\sim$ & 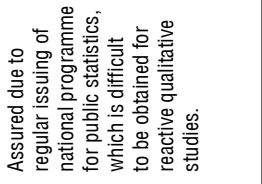 \\
\hline- & 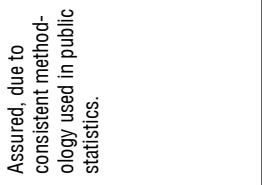 \\
\hline$T$ & 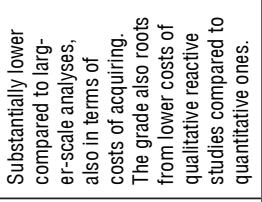 \\
\hline$T$ & 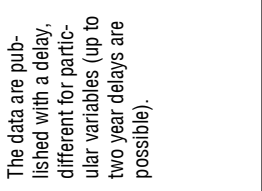 \\
\hline T & 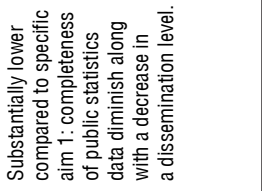 \\
\hline $\begin{array}{l}\frac{\mathbb{\pi}}{\mathbb{\pi}} \\
\frac{\pi}{5}\end{array}$ & 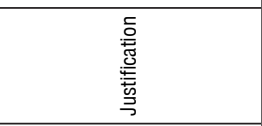 \\
\hline & 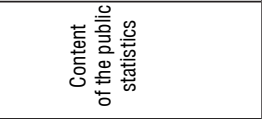 \\
\hline
\end{tabular}




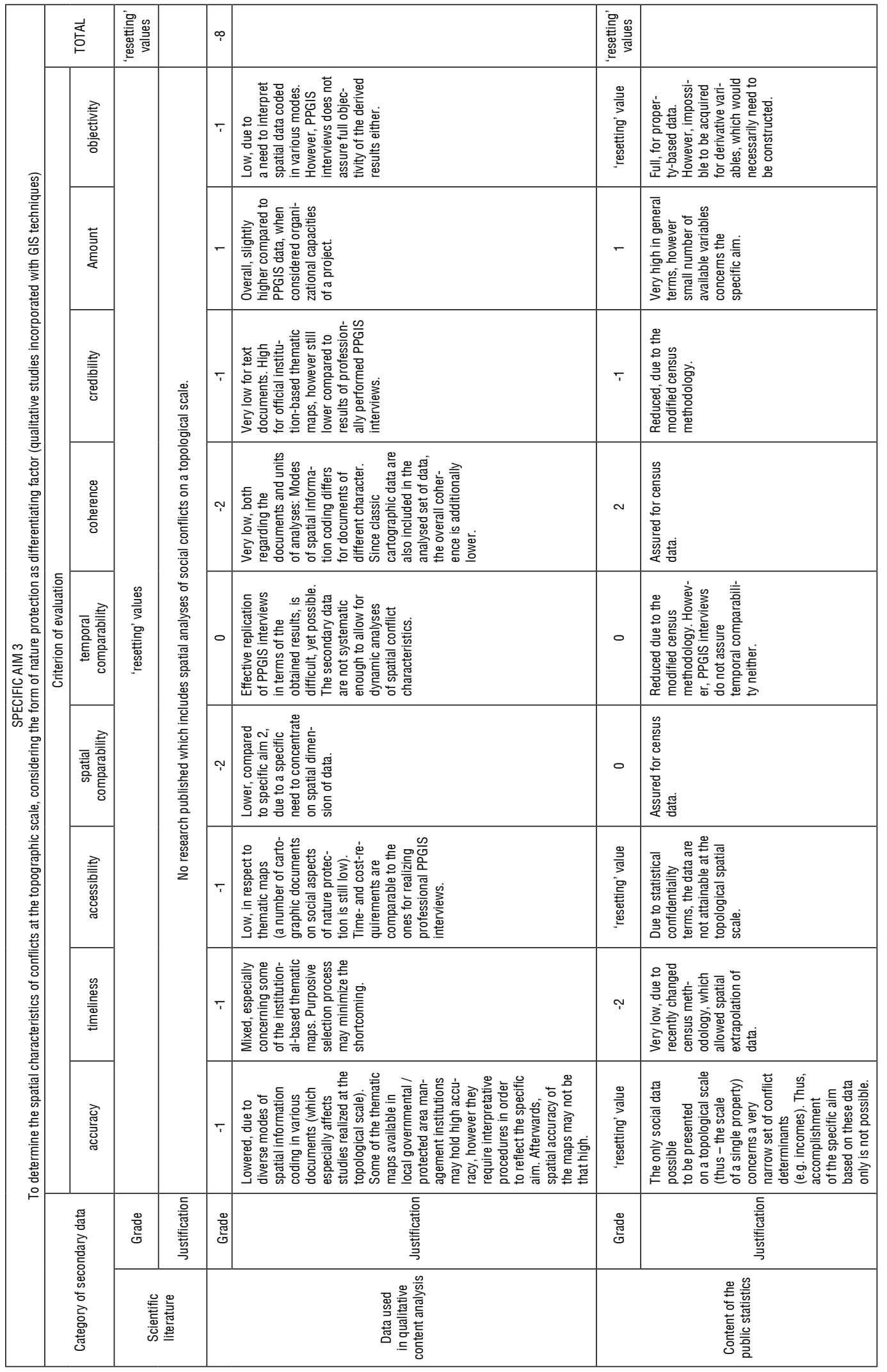

